RESEARCH ARTICLE

\title{
Varietas, Mediocritas and Annehmlichkeit: The Reception of the Classical Tradition in the Work of Josef Frank and Its Viennese Context
}

\author{
Caterina Cardamone
}

The theoretical work of the Viennese architect Josef Frank (1885-1967) illustrates a continuous reflection on the Italian Renaissance tradition. This study seeks to gain new insights into Frank's complex and optimistic 20th-century 'classicism' and to identify the Renaissance categories Frank used in his written, and to a lesser extent, in his built work as authoritative instruments in his search for a modern architecture.

The starting point of this paper is an analysis of both the classical education Frank received in Vienna at the Technische Hochschule (TH) and his doctoral thesis on Leon Battista Alberti of 1910. The work of his closest colleagues and former students at the TH provided a Viennese context for Frank's anthropocentrism, which is based on classical categories rather than a search for anthropometric norms. Frank's attention to man leads rather to a sort of 20th-century humanism, a 'humane' architecture focusing on imperfection, agreableness, moderation, and variety, which he theorizes in his seminal essay Architektur als Symbol from 1931.

Frank's continuous reflection on the Renaissance tradition is part of the contemporary debate on modern architecture in Vienna and in German-speaking countries. He developed, from his education about history, an alternative model for modern architecture. The aim of this article is to provide a more diverse reading of that debate and to shed light on the many facets of the reception of classical tradition in the 20th century.

\section{Introduction}

Josef Frank (1885-1967) is generally acknowledged as one of the most influential Austrian architects and theorists of the 20th century and one of the most acute critics of Germanic modern architecture, a 'dissenting voice' (Long 2002: 103) from within its very institutions - the Austrian Werkbund and the first CIAM (Welzig 1998; Long 2002). With his theoretical work, Frank contributed to a specific Viennese vision of modern architecture, less dogmatic in formal prescription and less trenchant in its relationship with history than the writing of many of his German colleagues.

Two aspects of Frank's education - his study with Carl König (1841-1915) at the Technische Hochschule (TH) in Vienna and the writing of a doctoral thesis on the original form of Leon Battista Alberti's religious buildings ('Ueber die urspruengliche Gestalt der kirchlichen Bauten des Leone Battista Alberti') (Frank 1910) - provide evidence of a robust classical background. The relationship between Frank's education in Renaissance architecture and his later work has rarely been tackled in studies about Frank (Welzig 1998: 15; Long 2002: 16-17). His

Independent scholar, IT

caterina.cardamone@gmail.com early reading of Leon Battista Alberti's De re aedificatoria, I contend, proved crucial to his later theoretical work. In particular, three categories that depend on Alberti's writings, varietas, mediocritas and Annehmlichkeit, substantially influenced Frank's approach to modern architecture.

The Viennese context provides further elements by which to understand the originality of Frank's reception of the classical tradition. While Frank's colleagues and fellow TH students, such as Oskar Strnad (1879-1935), Viktor Lurje (1883-1944) and Walter Sobotka (1888-1972), frequently employ abstract and erudite quotes from the classical repertoire in their built work, Frank himself produced architecture that reveals no interest in a formal vocabulary. In this sense, he is not a 'classicist', as he acknowledges late in his career (Frank to Sobotka, Stockholm 22 January 1962, in Sobotka 1970: 398). Instead, his reception of the classical tradition is mostly conceptual. In his writing, he focuses on a tradition of thought that is occasionally, unexpectedly and unconventionally translated into his built work. This tradition is also implicit in his writings, a circumstance that opens multiple historiographical questions concerning Frank's reticence about his Renaissance sources. Frank's reception of the classical tradition has therefore no affinities with his contemporaries' reception and search for anthropometric ratios. 
This study retraces elements in both Frank's theoretical work and, to some extent, his built architecture to argue and confirm this reading. Certain passages of his writings, as well as the multiplicity of formal solutions and the eclecticism of his early interiors, seem to echo the Antique and Renaissance category of varietas. His consistent theoretical search for moderation, a via media, a middle road free from the pathos of Moderne, could be also read as a 20th-century translation of the second key concept, mediocritas. His attention to Annehmlichkeit (agreeableness, comfort), the starting point of a nondogmatic functionalism, also has deep classical roots. Even the 'Bordel Frank', as Paul Meller (1902-43) defined Frank's interiors of the Weissenhofsiedlung in Stuttgart (Paul Meller to J.J. Pieter Oud, 31 August 1927, in Kirsch 1987: 96), in its vivid eclecticism, recalls nonconventional classical values: varietas and attachment to life - in Frank's view, the profoundest essence of classical culture, which should be the basis of modern architecture (Frank 1931b: 49, 135).

\section{An Education in Classical Models}

Like many of his fellow Jewish colleagues working in Vienna during the 1920s, Frank studied architecture with Carl König at the TH (Kristan 1999: 20-21; Kristan 2007: 35; Long 2018: 129-30). The classical education at the TH in Vienna had a decisive influence after WWI on the generation that reflected on the meaning and scope of modern architecture, and their teacher, König, and his assistant, Max Fabiani (1865-1962), played an important role in their curriculum (on König, see Pozzetto 1984: 27-29; Long 2001: 24; on Fabiani, see Pozzetto 1983; Pozzetto 1998). As Mario Pozzetto points out, no other contemporary school of architecture proposed such a robust training in architectural history, which added up to more than 420 hours in the four- or five-year course (Pozzetto 1984: 27). Less attention has been paid to the role played by the eclectic architect Karl Mayreder (1856-1935). Mayreder was König's assistant between 1877 and 1885, and then professor and dean at the TH between 1904 and 1908. ${ }^{1}$ Frank seems to have shown a particular interest in Mayreder's classes, which he attended throughout his fouryear course at the TH, from 1903 to 1908 (Cardamone 2002: 11-18). In 1910, Mayreder, along with the art historian Josef Neuwirth (1855-1934), supervised Frank's doctoral thesis on Alberti.

In his first year at the TH, 1903-4, Frank attended Mayreder's Architektonische Formenlehre course, an overview of 'decorative forms derived from textile arts, in order to highlight eurythmy, symmetry, proportion and direction' in architecture (Lektionskatalog 1903-4: 37-38; Cardamone 2002: 11-12). The course appears to have followed Gottfried Semper's Der Stil not only in its contents - the study of textile arts - but also in its structure, with a close reference to the formal principles discussed in Semper's Prolegomena. The reference to Der Stil became explicit in a document dated 1915, from which we know that König, who taught Architektonische Formenlehre before Mayreder, had 'repeatedly adapted and enlarged the train of thought [of Der Stil] to meet the needs of ex cathedra lessons' (Mayreder 1915: 529), the lectures that, together with practical exercises, constituted the bulk of the curriculum at the $\mathrm{TH}$.

Different interpretations of Semper's writings marked Viennese architecture at the turn of the century. His theoretical work not only formed the basis for the constructed and written works of Otto Wagner (1841-1918) and his students, and for the oeuvre of Adolf Loos (18701933), but it was also at the core of the education in Renaissance architecture at the TH (König 1901: 48-49; König 1904: 5-7; Moravánszky 1988: 67-86; Oechslin 2002a; Nerdinger and Oechslin 2003: 430-489; Franz and Nierhaus 2007).

König's students were aware that they belonged to a school (Kristan 1999: 23; Long 2001: 23-25). They perceived it as distinct from the Wagnerschule of the Akademie der bildenden Künste and described it as 'basically of a different nature' (Sobotka 1970: 363). They were convinced, moreover, that it was their school, with its focus on the classical tradition, and not the Wagnerschule, that led to the particular Viennese understanding of modern architecture as 'a new evolutionary direction based on traditional models' (Sobotka 1970: 363). For a contemporary observer, like Sobotka, modern architecture in Vienna could only be based on the knowledge of classical tradition and not on Wagner's presumed caesura with history. König's writings confirm Sobotka's statement. With its eclectic understanding of the classical tradition and tolerant approach to formal questions, König's teaching at the beginning of the century could in fact have set out in nuce the critical instruments of the generation working during the 1920s (Payne 2008; Cardamone 2018; Cardamone and Torello, forthcoming).

In König's writings, formal questions are not the focus of the discussion. This point emerges clearly in König's inaugural speech as a rector for the academic year 1901-2:

Observe the porches of the Karlskirche, when its stairs and atrium are filled with people, enter the space of the dome, where the devoted are gathered and you will feel the power of architectural forms which are essentially the same whether people are wearing clothes of the 18th- or of the 20th-century. (König 1901: 52-53)

This passage exerted a profound influence on the young audience. With an implicit criticism of Wagner's Moderne Architektur, König affirmed that modernity had nothing to do with the establishment of a new formal repertoire. Precisely this position constituted the bulk of the Viennese attack on the German approach to modernity during the 1920s.

In the same lecture, König interprets classical architecture - in this case the ancient Greek and Italian Renaissance - as the result of an eclectic process. Eclecticism had to be considered as a fundamental attitude of the classical tradition and of each period that refers to it as a model (König 1901: 54-55). Antique and Renaissance architecture was the result of a process of eclectic assimilation, and it is the process itself that deserves attention as a model for contemporary practice (König 1901: 55; Cardamone and Torello, forthcoming). 
In his lecture, König also confirms the role of Semper as a guide for modern architecture. In High Renaissance architecture, says König, Semper found a practical and theoretical model that can serve for contemporary architecture - a model, indeed, that is not exclusively formal (König 1901: 48-49; Hvattum 2004: 87-113). The essence of classical art, in König's reception of Semper's writings, was in the 'Princip der Stoffverneinung', the negation of material, which was a contrast to Gothic art, whose form is determined by material and technical factors (König 1901: 49). Semper 'indicates the example of nature, which conceals the skeleton of highly developed animals, without contradicting it in their external appearance' (König 1901: 49; Oechslin 2003: 62-66). It is well known that this idea - the non-correspondence between construction and cladding that constitute, in König's opinion, the core of the classical tradition - featured prominently in the Viennese theoretical context of the time (Frank 1910; Oechslin 2002a).

In December 1910, when Frank defended his thesis, the title of 'Doktor der technischen Wissenschaften' (doctor of technical sciences) had been instituted at the TH less than a decade earlier, in 1901. Among the 28 theses defended before 1919, more than half (16) treated a historical subject. It is interesting to note, however, that together with Hermann Egger's dissertation on the architectural drawings of the k. k. Hofbibliothek (1903), only two theses dealt with the Italian Renaissance: Frank's thesis and that of Max Theuer (1878-1949) (Abhandlungen 1955: 27). Both analysed the work of Alberti and both came from König's milieu. ${ }^{2}$ Two of the students who wrote a doctoral thesis, Strnad and Oskar Wlach (1881-1963), had been part of Frank's closest circle since at least 1904 (Welzig 1998: 15, 31; Long 2002: 22-27; Prokop 2016). In their dissertations, both dealing with historical subjects, Semper's influence is strong (Strnad 1904; Wlach 1906). Strnad presented his thesis, on the decorative principles of early Christian architecture, in 1904 (Cardamone 2002: 35-43). His work applies Semper's 'Prinzip der Dekoration' directly to the case study of early Christian art, in a biased reading of Semper's writings (Quitsch 1962: 16; Van Eck 2004: 61-63; Hvattum 2004). In Wlach's thesis, which he defended in June 1906, Semper is an indisputable reference both in methodology - to comprehend historical laws in order to define a contemporary praxis - and in choice of subject matter: incrustation and the use of colour in architecture (Cardamone 2002: 43-47; Hvattum 2004: 11; Hub 2015). The choice of the historical period, too - the Florentine proto-Renaissance - likely depends not only on Burckhardt but also on Semper, who had already introduced the notion of Vorrenaissance in Der Stil (Semper 1863: 331; Burckhardt 1868: 20-35, Tauber 2016: 80). Wlach's dissertation concludes with a chapter in which he applies to contemporary Viennese architecture the norms for the use of colour that he identified through his analysis of historical architecture. He thus points out repeated errors in the contemporary use of colour, for instance in Otto Wagner's well-known Majolikahaus (1898-99; Wlach 1906: 79-82; Hub 2015; Cardamone 2016).

\section{Annehmlichkeit, Ornament, Artifices and Cladding: Frank's Reading of Alberti}

In this general context, Frank's doctoral thesis deserves particular attention for different reasons (Frank 1910). ${ }^{3}$ The first is the unconventionality, among studies from the beginning of the 20th century, of his choice of topic - Alberti. In Renaissance studies in the department of art history at the Viennese university, in fact, Alberti was identified as an amateur, 'ein Dilettant', and his work was discarded because it was seen as the principal model for the 'worst neo-Renaissance architecture of the 19th-century' (Dvořák 1927: 126-27; Strzygowski 1907: 47; Marchand 1994). The TH context was similar. Programmes, curricula and students' drawings, as well as various issues of Wiener Bauhütte that allow a partial reconstruction of TH study trips to Italy, show that, with a few interesting exceptions, Quattrocento architecture and Alberti's buildings were generally ignored. Visits to Mantua were limited to the Palazzo Ducale and the Palazzo del Te; almost no building by Alberti in Florence drew the travellers' attention (Cardamone 2005: 103-4; Hub 2015). One noteworthy exception is a trip to Rimini in 1907 organised by Max Fabiani, in all likelihood to visit Alberti's Tempio Malatestiano (Welzig 1998: 15). ${ }^{4}$ The interest that Fabiani had in Alberti, and particularly in the translation of De re aedificatoria, also emerges in an archival document dated 1918 (Fabiani 1918). ${ }^{5}$

Not only was the subject unusual at the time, but Frank's thesis proposes an original understanding of Alberti's work (Cardamone 2018: 84-93). Two aspects stand out: a profound reflection on the question of cladding and a particular reconstruction of Alberti's triad. In his reading of De re aedificatoria, Frank focuses on Schönheit and Festigkeit, clearly the German translations for venustas and firmitas, and rather conventional categories for interpreting the work of Alberti; the originality of Frank's reconstruction of the triad lies in the category he proposes as the third term - Annehmlichkeit (1910: 52). Frank's choice requires some explanation. A comparison with Theuer's German translation of De re aedificatoria, of 1912, could help define - or complicate - Frank's understanding of Annehmlichkeit. In Theuer's edition, the term occurs mainly in the plural form, Annehmlichkeiten, for example in the preface, in a passage about the architect as 'omnium commoditatum inventor' (Alberti 1541: f. 2v; Alberti 1912: 14: "Erfinder aller Annehmlichkeiten"). However, Theuer does not consistently or exclusively use Annehmlichkeit as a translation for commoditas. The term also occurs as a translation for amoenitas (pleasantness, Alberti 1541: 12r; Alberti 1912: 47), voluptas (pleasure, 1912: 145), gratia (grace, 1912: 345) and iocunditas (agreeableness, 1912: 478). The semantic contours of Annehmlichkeit are therefore not neat; in the general context of Frank's writings, the notion could correspond to a sort of joyful and pleasant commoditas (Cardamone 2018).

Frank's focus on Annehmlichkeit marks a critical juncture in the 20th-century reception of classical tradition that clearly emerges in further comparisons of Frank's dissertation with Theuer's translation of De re aedificatoria. Both Theuer and Frank consider Alberti as the first modern architect, but they understand Alberti's modernity 
differently. Theuer's idea appears to be more clearly influenced by the contemporary architectural discourse:

The great scale of [Alberti's] principles, his effort to analyse architecture ... above all in terms of its functionality, his need of light and air, his request for a layout respecting hygienic needs, ... his attention to the human being, ... all these elements make him the first modern architect. (Alberti 1912: liii; Cardamone 2018: 89)

In Theuer's reading, De re aedificatoria legitimises some of the formal principles proposed at the beginning of the 20th century: building from the inside out, zweckentsprechend, or respecting the function, and composing volumes and masses according to proportional rules in a three-dimensional conception of space (Alberti 1912: 1-li, quoting Burckhardt 1868: 166).

In his thesis, Frank saw a different modernity at work in Alberti:

For the first time, [Alberti] applied the classical Roman style to modern conditions and with this deed, he founded the modern style. And when, as was so often the case, architecture became to [sic] baroque in its style, new interpretations of classical Roman principles were developed for the new circumstances; this marks the great steps forward in the evolution of architecture. (Frank 1910: 107)

In Frank's reading of Alberti's modernity, it is a rebirth of classical tradition that implies the 'evolution of architecture'. In this case, Frank's position is remarkably close to that of Adolf Loos, for whom the cyclic revival of classical architecture is the only means of progress (Loos 1898: 66; Loos 1913: 65; Oechslin 2002b: 66; Trevisiol 1996).

A divergence between Frank and Theuer also emerges in their attempts to reconstruct Alberti's triad through appropriate translations. In addition to venustas and firmitas, Theuer focuses on utilitas, or Zweckmäßigkeit. confirming the astonishingly modern core of Alberti's work (Alberti 1912: liii). Zweckmäßigkeit, functionality, is a term that echoes the contemporary German architectural debate and contrasts with the light pleasantness of Frank's Annehmlichleit. The distance between Theuer and Frank is still more evident in the priorities they ascribe to these categories. Frank considers venustas as the most salient element of the triad (Frank 1910: 53). In the introductory pages of his dissertation, the question of beauty and ornament is at the core of his analysis (Cardamone 2002: 85-86; Cardamone 2018: 89-91). Beauty, he says, "is an inherent quality of such nobility, that all wisdom and artifice must be employed in order to bring it forth' (Frank 1910: 55). In Frank's reading, classical tradition requires the use of architectural artifice; Alberti did not adhere to the notion of structural honesty so appreciated at the beginning of the 20th century. Instead, Alberti apparently subordinated the structure to the aesthetic qualities of the architectural work.

The same privileging of artifice over construction is at work in Frank's twenty watercolour drawings of Alberti's religious buildings that illustrate his dissertation, which he attempts to reconstruct according to his understanding of Alberti's original intent. This is most evident in the case of the church of San Francesco in Rimini, also referred to as the Tempio Malatestiano, the only work that Frank affirms to be unanimously attributed to Alberti in 19th-century historiography (Frank 1910: 60). While Max Dvořák (1874-1921) had criticised its façade for not corresponding, in its profile, with the section of the 13th-century Gothic church on the site that Alberti transformed (Dvořák 1927: 127), Frank is far more tolerant in discussing the solution Alberti adopted for the Tempio. He appreciated the 'self-determination' of Alberti's cladding that he described as being 'liberated' from the Gothic building (Frank 1910: 63-65). In the case of Florence's Santa Maria Novella, Frank more explicitly identified the invention of a 'new type of basilica façade ... rebuff[ing] the previously inviolable principle of the stone-clad façade form' (Frank 1910: 91). Frank's passage on 'the dissonance of the applied façade' marked the starting point of a reflection on permanent principles in architecture (Frank 1910: 89; Cardamone 2018).

In his reconstructions, Frank reveals a predilection for heavy cladding. This is above all evident in his drawings of the façade of San Sebastiano in Mantua (Figure 1) and the interior of San Pancrazio, which also encompasses the Tempietto Rucellai, in Florence (Figure 2). In the pages where he writes about San Pancrazio, Frank conveys a certain aesthetic bias against its plain plaster interiors when he says they are articulated only by pilasters of pietra serena, which he describes as cold (Frank 1910: 94). In his reconstruction drawing, he presents instead a richly decorated interior that is modelled, he explains, on contemporary Quattrocento architecture and has the advantage of making the sacello appear clearer and lighter (Frank 1910: 94). He presents marble cladding and frescoes in a vivid Viennese setting (Cardamone 2006: 186-87). In so doing, Frank blithely ignores a passage in De re aedificatoria that recommends pure white plaster for the inside of religious buildings because it recalls the purity of life (VII, 10). This shows how Frank's reconstructions are rooted in his particular aesthetic vision and how Semper's Bekleidungsprinzip that was widely debated in Viennese circles possibly prevails over Alberti's recommendations.

\section{Varietas: Frank's Interiors around 1910}

From Frank's polychrome reconstructions of Alberti's religious buildings, an underlying notion emerges that would exert a persisting influence on Frank's built and written work: the Renaissance category of varietas. The notion is present throughout De re aedificatoria and De pictura, both quoted in Frank's dissertation (Frank 1910: 114, with reference to Leoni 1726; Frank 1931b: 84). In Frank's later writings the notion is fundamental for the definition of his 'humane' architecture (Frank to Sobotka, France [sic] 9 September 1961, in Sobotka 1970: 396; von Thun-Hohenstein, Czech and Hackenschmidt 2016: 40); it constitutes a basis for his anthropocentrism and it is charged with changing meanings throughout Frank's career. At the end of the 1920s and at the beginning of the 


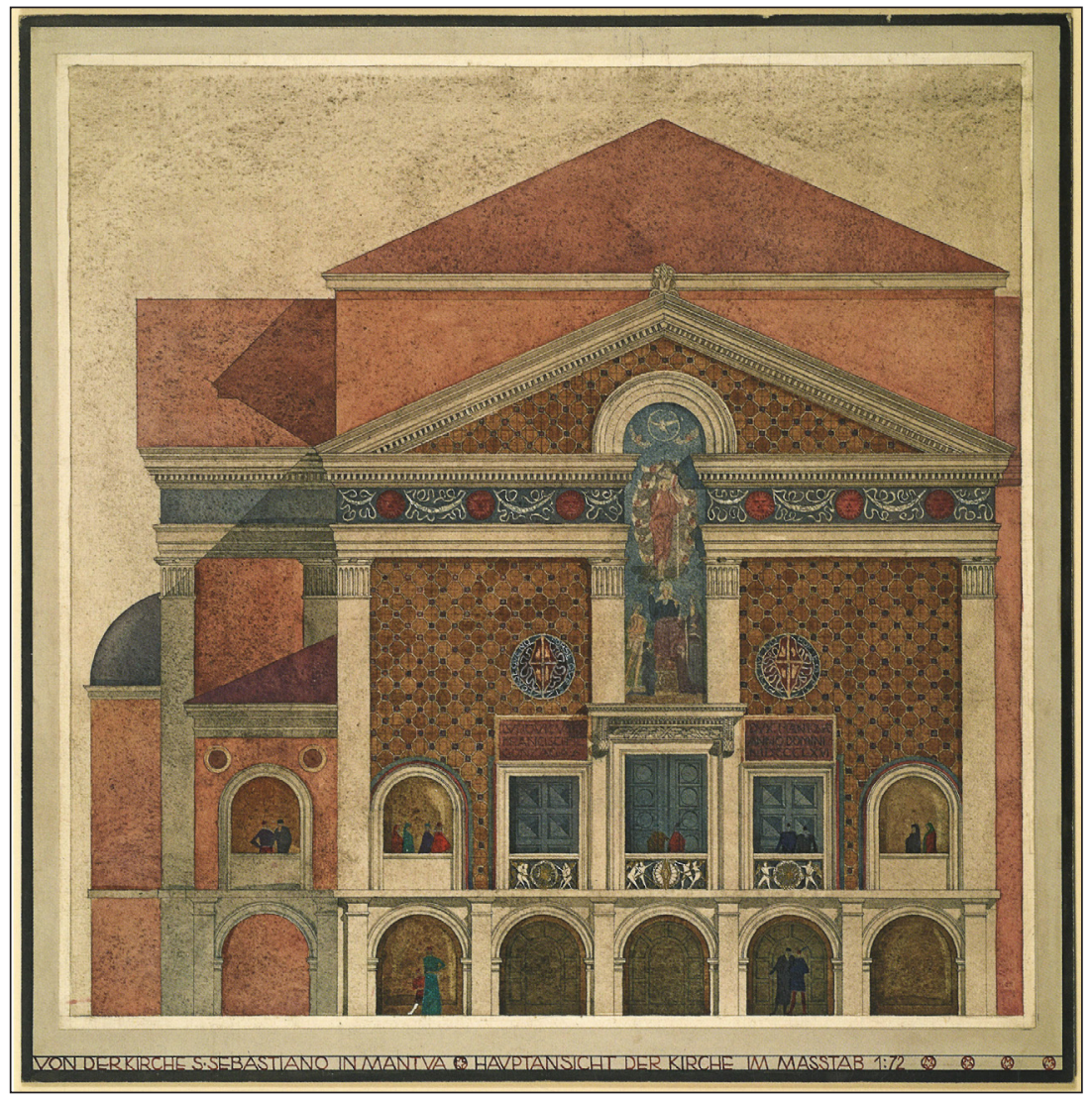

Figure 1: Josef Frank, reconstruction of the facade of San Sebastiano in Mantua. The drawing's caption reads, 'Von der Kirche S. Sebastiano in Mantua Hauptansicht der Kirche im Masstab 1:72'. From Frank's PhD dissertation (Frank 1910: plate 3).

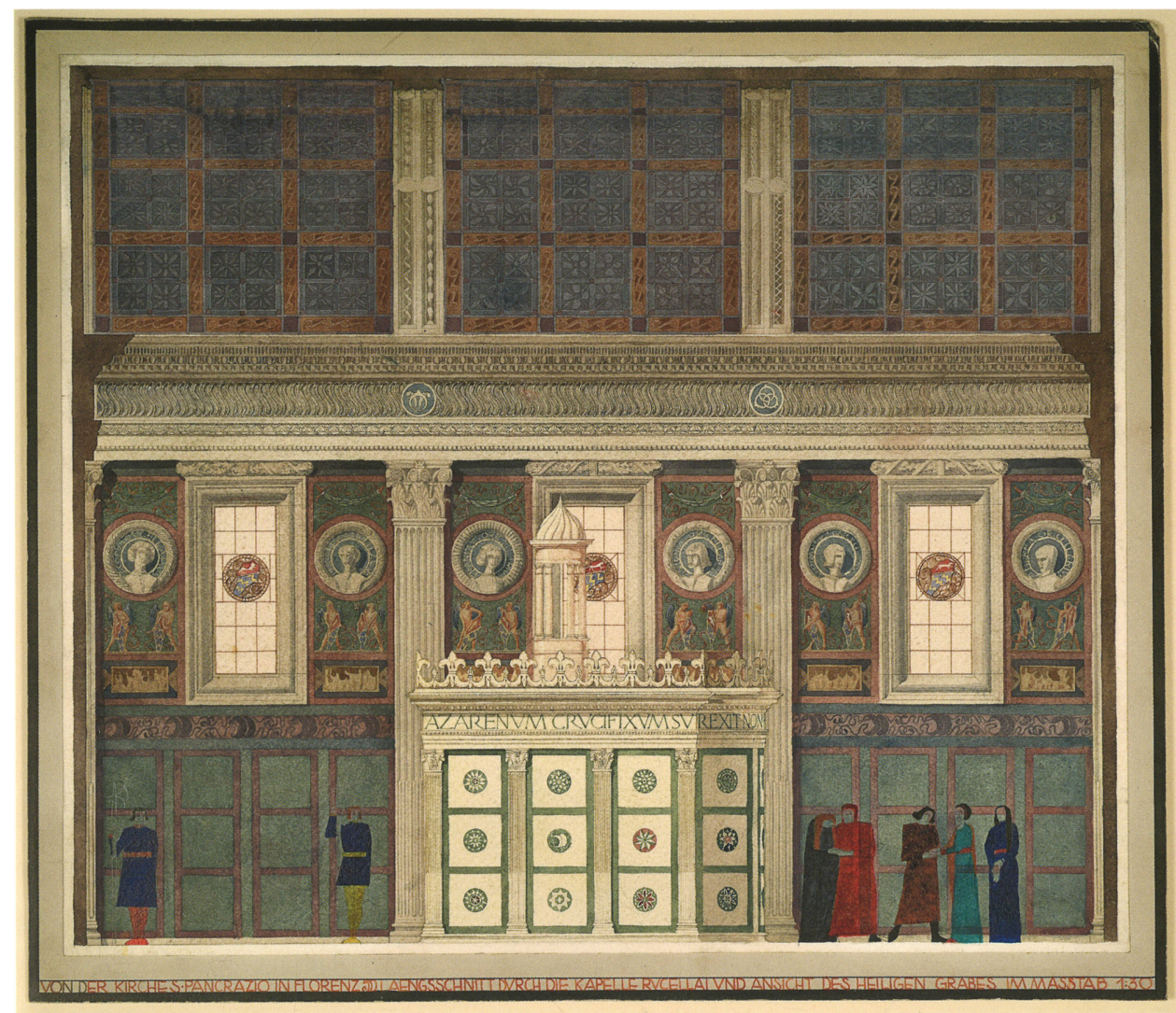

Figure 2: Josef Frank, reconstruction of the interior of San Pancrazio in Florence; the side of the Tempietto Rucellai is in the centre. The drawing's caption reads, 'Von der Kirche San Pancrazio in Florenz Laengsschnitt durch die Kapelle Rucellai und Ansicht des Heiligen Grabes im Masstab 1:30'. From Frank's PhD dissertation (Frank 1910: plate 2). 
1930s, in Frank's focus on man, varietas corresponds to the multiplicity and diversity of psychological needs that imply, as a response, a variety of functions and architectonic solutions (the topos in book IV of De re aedificatoria, Leoni 1726: I, 60v). In Frank's later writings, however, variety acquires new and more encompassing contours. It emerges as an experience of reality (Gosebruch 1957: 23031; Brinkmann 2003: 11-18) and it becomes a response to totalitarianism and its Weltanschauung, charged with strong ideological values such as pluralism and democracy (Cardamone 2016a; Frank post 1945?a: f. 26).

In Frank's dissertation, however, varietas still does not appear explicitly as a critical instrument but rather as an aesthetic leitmotiv in the watercolour plates that illustrate the text. Frank's interiors from around 1910 recall these watercolour plates, not only in their formal references to the Quattrocento (Figure 3) (Ott-Wodni 2015: 33-34; von Thun-Hohenstein, Czech and Hackenschmidt 2016: 40-41), but above all because of their intrinsic varietas. This quality was already clear to contemporary reviewers, 'der häufige Wechsel', or continual variation, being a main character of Frank's interiors in Wlach's review (1912: 42). In the Tedesko apartment of 1910, designed for his sister and brother-in-law, Frank used a strong polychromy as a means of creating unity. In his view, polychromy could absorb every modification of the interior arising from the changing lives and needs of its inhabitants (Wlach 1912: 43; Czech 1986: 24; Ott-Wodni 2015: 181-82). The Schwedische Turnschule in Vienna, also of 1910 (Figure 4), could be read as a further transcription of this notion of unity, because of its principled use of disparate ornamental patterns (Witt-Dörring 1996: 103; OttWodni 2015: 182-83). Here Frank also includes a painted strigilatum frieze, recalling the entablature frieze inside the church of San Pancrazio. ${ }^{6}$

In Vienna the critique of 'stilvollen' interiors and their uniformity began at the turn of the century, in 1898, with Loos' contributions to the Neue Freie Presse (Loos 1921).
Unity became one of the main topics in the Viennese debate of the 1910s and 1920s (Ottillinger 2009b: 18-22; Frank 1919). An article of 1921, in which 'antique variety' is proposed as a model for contemporary interiors, confirms that the historical context of the notion was evident at that time (Sobotka 1921: 176). The classical matrix of the category was also clear in the 'small circle around Oskar Strnad and Viktor Lurje', which included Frank and with which Sobotka, the author of the 1921 article, had intensive exchanges (Wlach 1912: 41; Prokop 2016; Cardamone 2002: 223).

The most appropriate example of this reflection on variety is a project by Frank, Strnad, Hugo Gorge (1883-1934) and Viktor Lurje - two rooms in the Jahresausstellung of 1911-12 in the Imperial Royal Austrian Museum for Art and Industry (the k.k. Österreichisches Museum für Kunst und Industrie, ÖMKI) (Figure 5). Contemporary reviewers appreciated the exhibition rooms for their 'powerful atmosphere' (Fischel 1911: 627), which resulted from a resolute use of colour, such as in the coffered ceiling that recalls the solution employed in the Tedesko apartment (Ott 2009: 18). Once again, this polychrome variety was understood as a clear reference to a living tradition:

There are many artists today, with clear modern sensibilities and aspirations, who see themselves as followers of the past, possessing specific and essential knowledge of historical forms ... They sink conspicuously into ancient and ever more ancient art, and they aspire to approach the art of the past through modern principles of composition. (Fischel 1911: 626-27; Ottillinger 2009b: 19)

Some months later, in the Gartenhalle of the Frühjahrausstellung of the ÖMKI, Strnad and Lurje proposed again a surprisingly eclectic composition that contemporaries considered with 'astonishment' (Cardamone 2002: 138-39; Planer 1912-13: 180) (Figure 6). If the work of

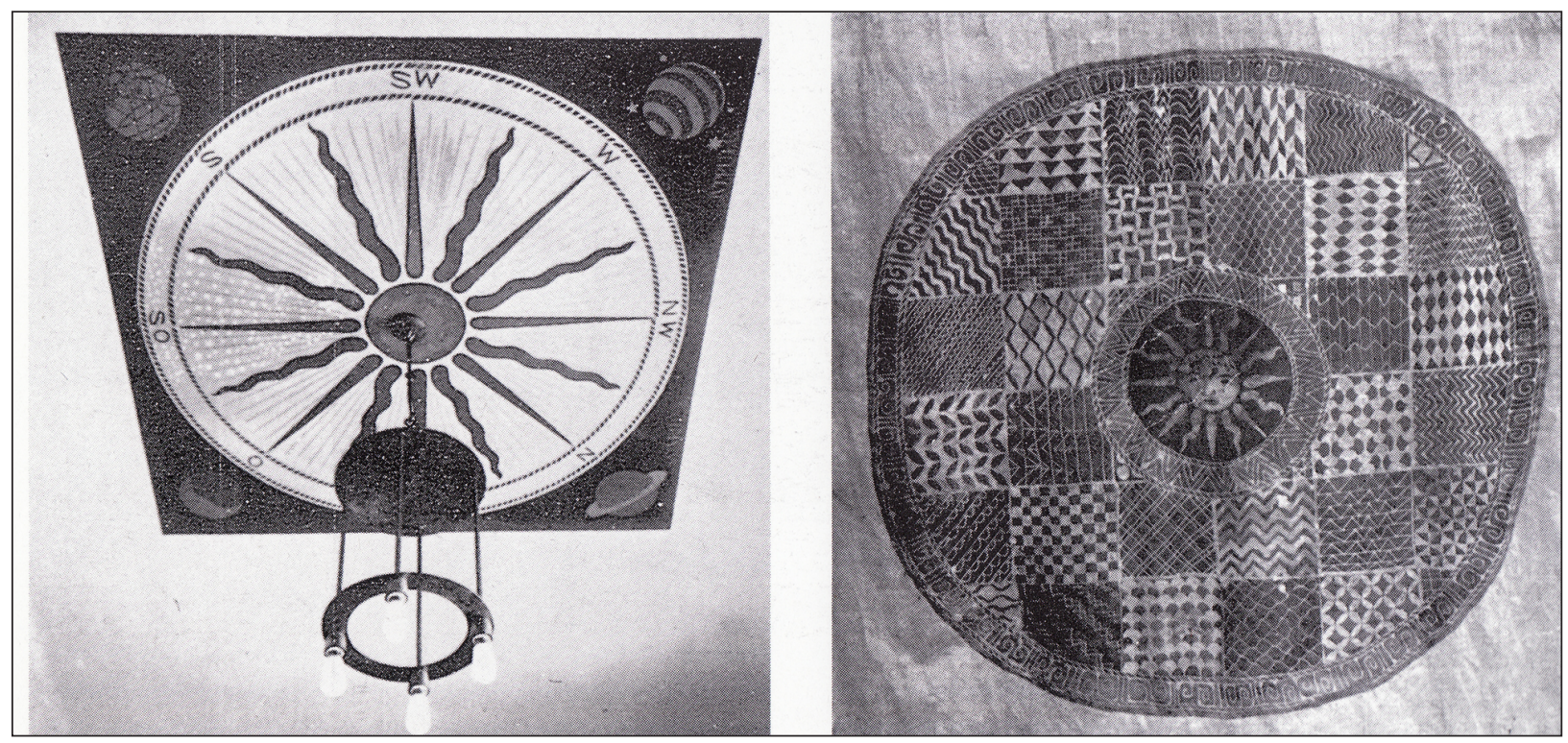

Figure 3: Josef Frank, detail of the ceiling in the hall of the Tedesko apartment in Vienna of 1910, and batik pattern for the same apartment (Welzig 1998: 26). The sun in the batik pattern (right) quotes Alberti's facade of Santa Maria Novella in Florence. 


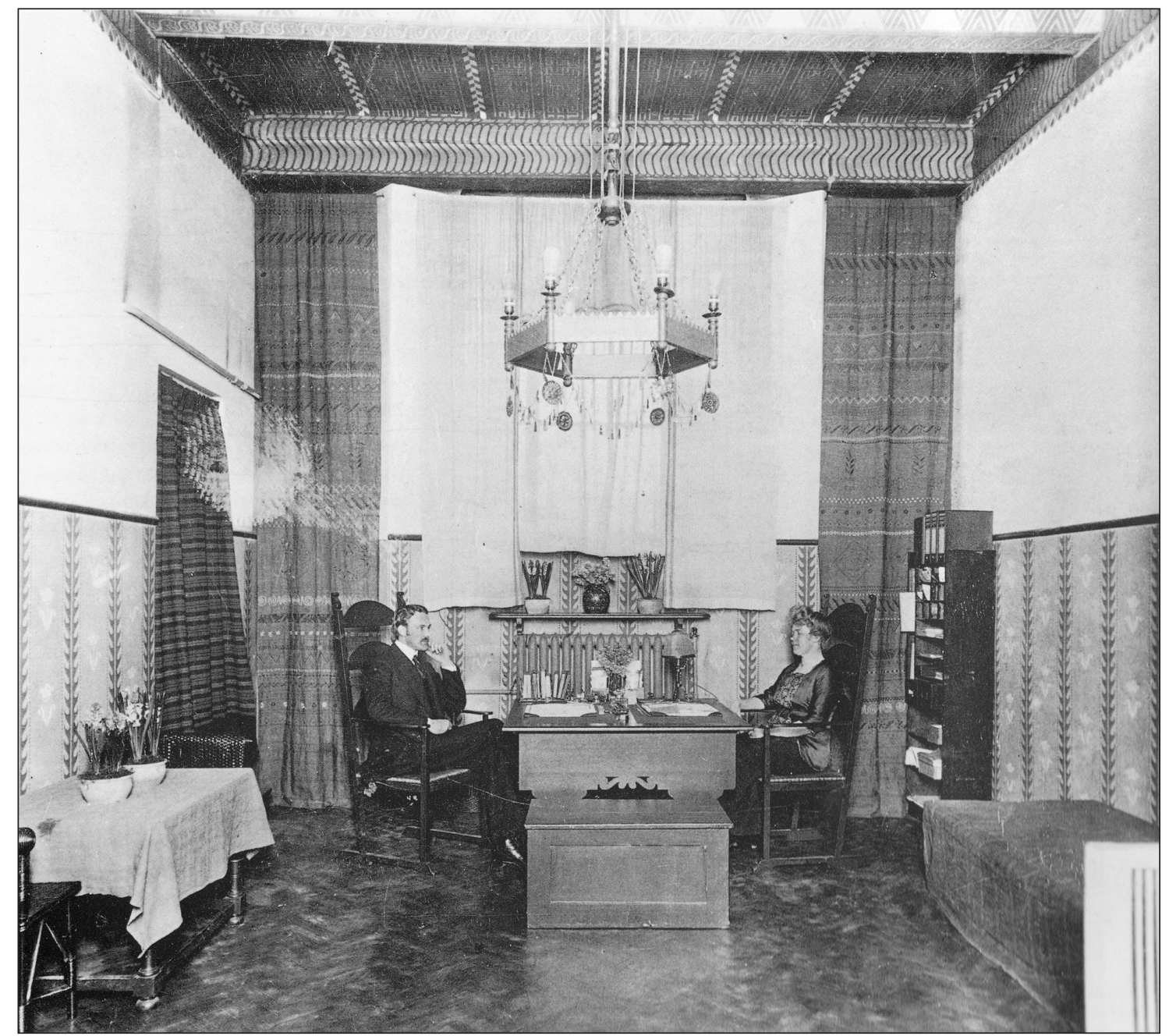

Figure 4: Josef Frank, reception room of the Schwedische Turnschule, Vienna, 1910 (Welzig 1998: 24).

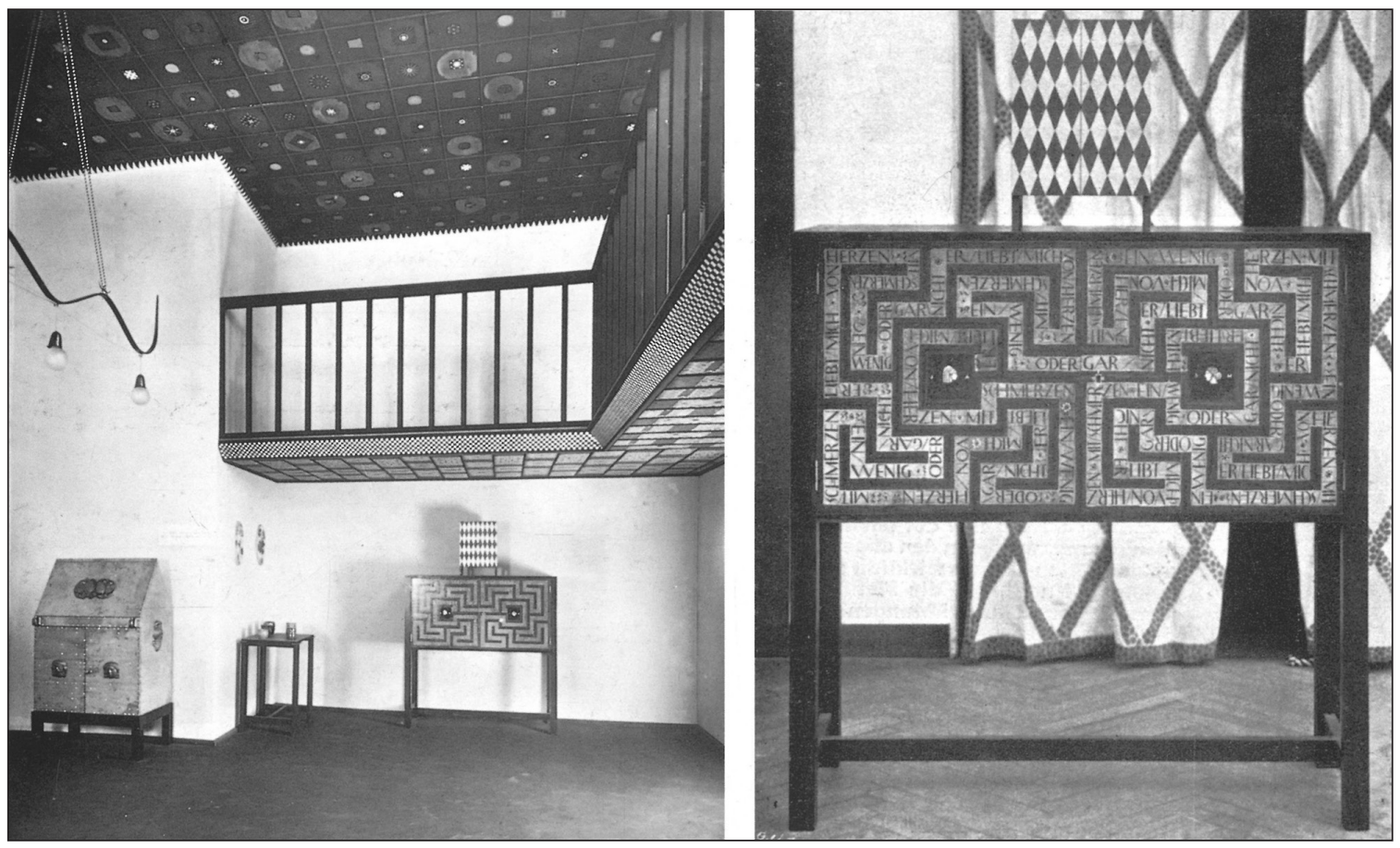

Figure 5: Left: Josef Frank, Oskar Strnad, Hugo Gorge and Viktor Lurje, interior for the 1911-1912 exhibition at the Österreichisches Museum für Kunst und Industrie. Right: Josef Frank, painted cabinet presented at the exposition, designed for the Tedesko apartment, 1910 (Welzig 1998: 32). 


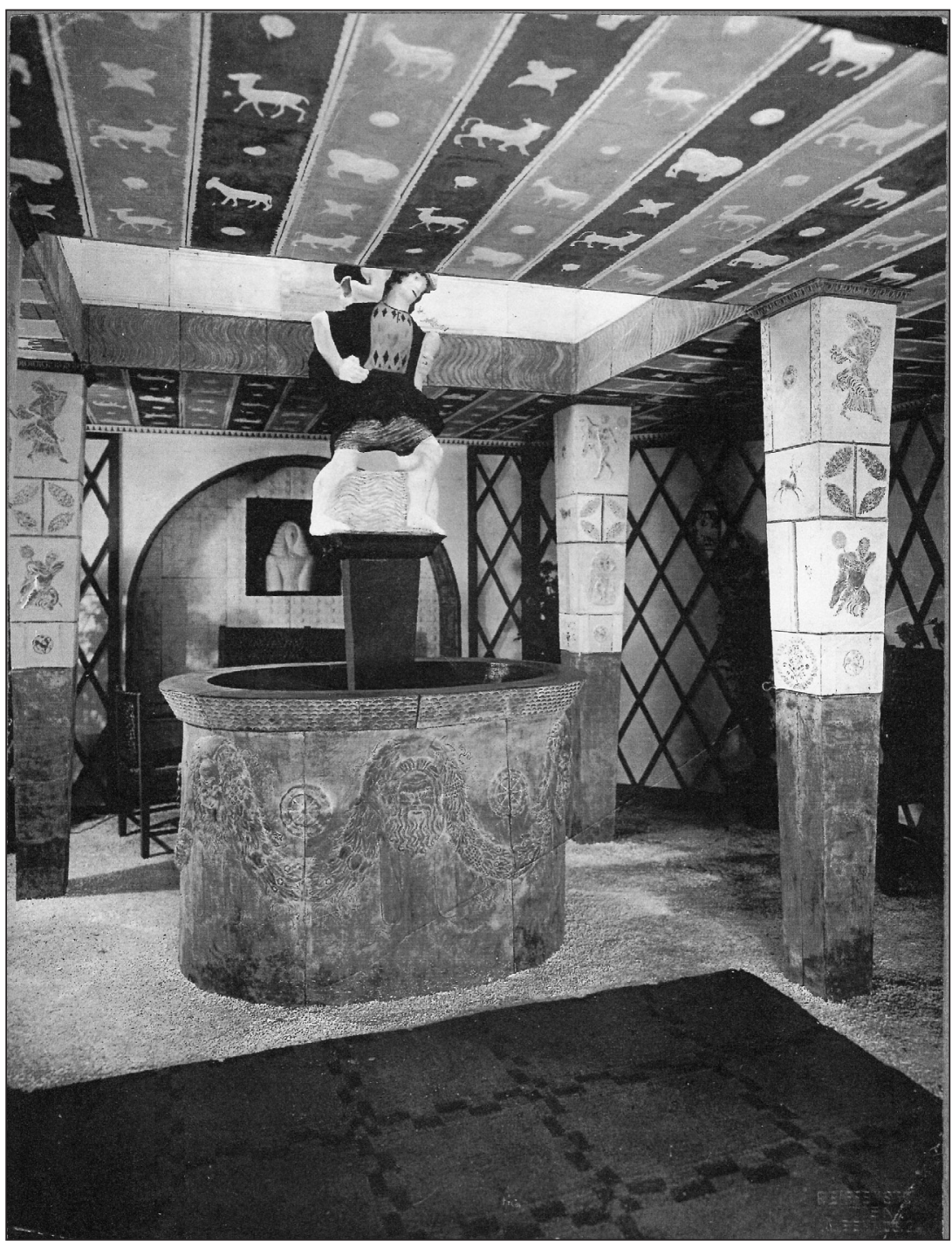

Figure 6: Oskar Strnad, design for the Frühjahraussellung (spring exhibition) of the Österreichisches Museum für Kunst und Industrie, 1912 (MAK V.S. 430, K.I. 13.823/1). Photo: (c) MAK - Museum für angewandte Kunst, Vienna.

the circle could be labelled traditionalist from a formal point of view, contemporary reviewers did not perceive their traditionalism as a contradiction to their quest for a different modernity.

The 'small circle', in fact, made extensive use of abstracted elements from a classical repertoire - a refined abstraction in the classical repertoire being also, with different facets, a constant feature of Viennese architecture around 1910 (Rukschcio-Schachel 1982; Trevisiol 1995). In the interiors of the gymnasium of the Schwedische Turnschule (Figure 7), Frank places painted pediments above windows, almost unrecognisable as classical features, that are similar to those used by Strnad in some of his buildings (Figures 8 and $\mathbf{9}$ ).

The schematic pediments in the interior of the Hellmann apartment of 1914 (Figures 10 and 11) bear perhaps the greatest resemblance to the ones designed by Frank in the Turnschule (Ottillinger 2009a: 64-71). The inclusion of such elements in these interiors could be read as an erudite reference to Early Renaissance models, such as the Sala di Ercole e Iole in the Palazzo Ducale of Urbino.
Other examples in Strnad's work confirm his strong interest in abstracted motifs derived from a classical repertoire. For the exterior of Haus Hock (1912-13), an asymmetrical main entrance is marked by a Doric portico with a high pediment (Cardamone 2002: 151-82; Meder Fuks 2007: 136)..$^{7}$ The columns, without a base and with schematic capitals, were not fluted but facetted, a solution similar to that of the Heilig-Geist-Kirche (1910-13) by Jože Plečnik (1872-1957). The entablature, reduced to the frieze, is also schematic. Because of the steep slope, the solution to enter the villa was a basis, following antique and Renaissance models (Figure 12).

In the objects designed by Lurje for the Wiener Werkstätte, beginning in 1919, iconographically precise quotes from the Antiquity and the Italian Renaissance undergo a similar process of abstraction and reduction (Figures 13-17). ${ }^{8}$ This is most evident in many of his intarsia works, documented through the pages of Deutsche Kunst und Dekoration, such as the venus pudica exhibited in the Kunstschau of 1920 (Steinmetz 1921: 187; Lexicon 1994: 202 and Lexicon 1984: 52; Cardamone 2002: 194-95) (Figure 14). 


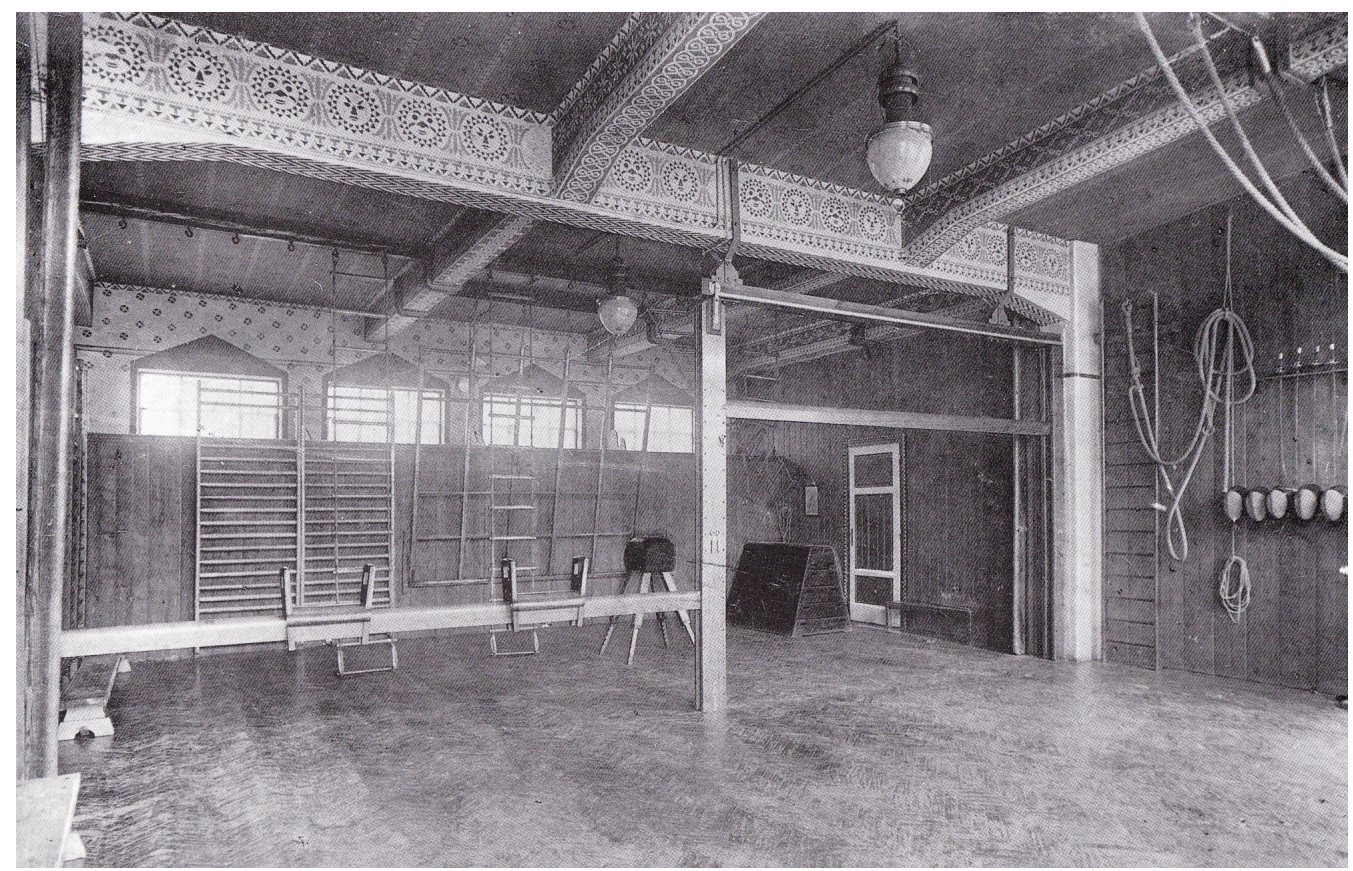

Figure 7: Josef Frank, Gymnasium in the Schwedische Turnschule, Vienna, 1910 (Welzig 1998: 25).

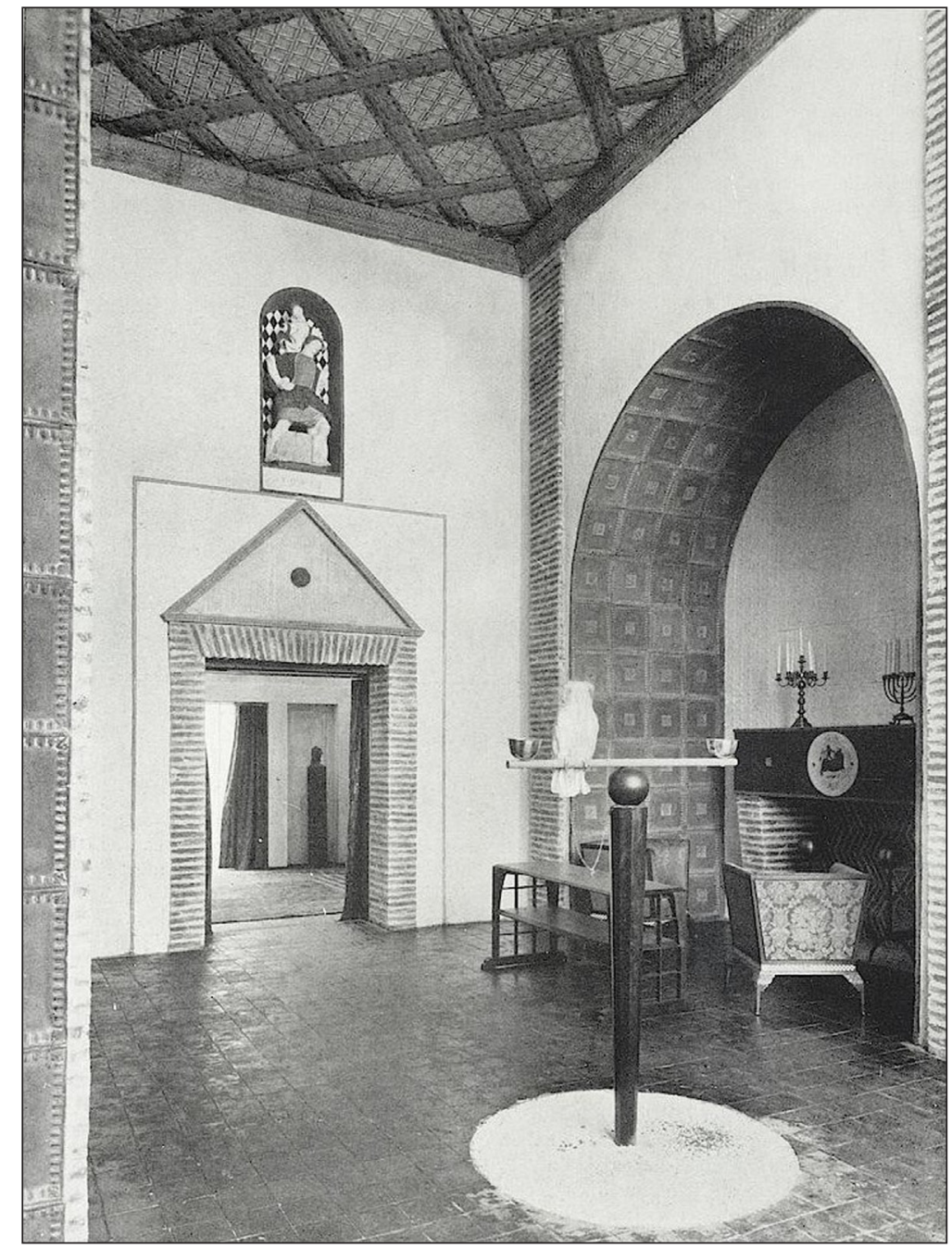

Figure 8: Oskar Strnad, Gartenhalle in the Frühjahrausstellung of the Österreichisches Museum für Kunst und Industrie, 1912. Deutsche Kunst und Dekoration, Bd. 31 1912-13: 192 (MAK V.S. 430, K.I. KI 7835/27). Photo: @ MAK - Museum für angewandte Kunst, Vienna. 


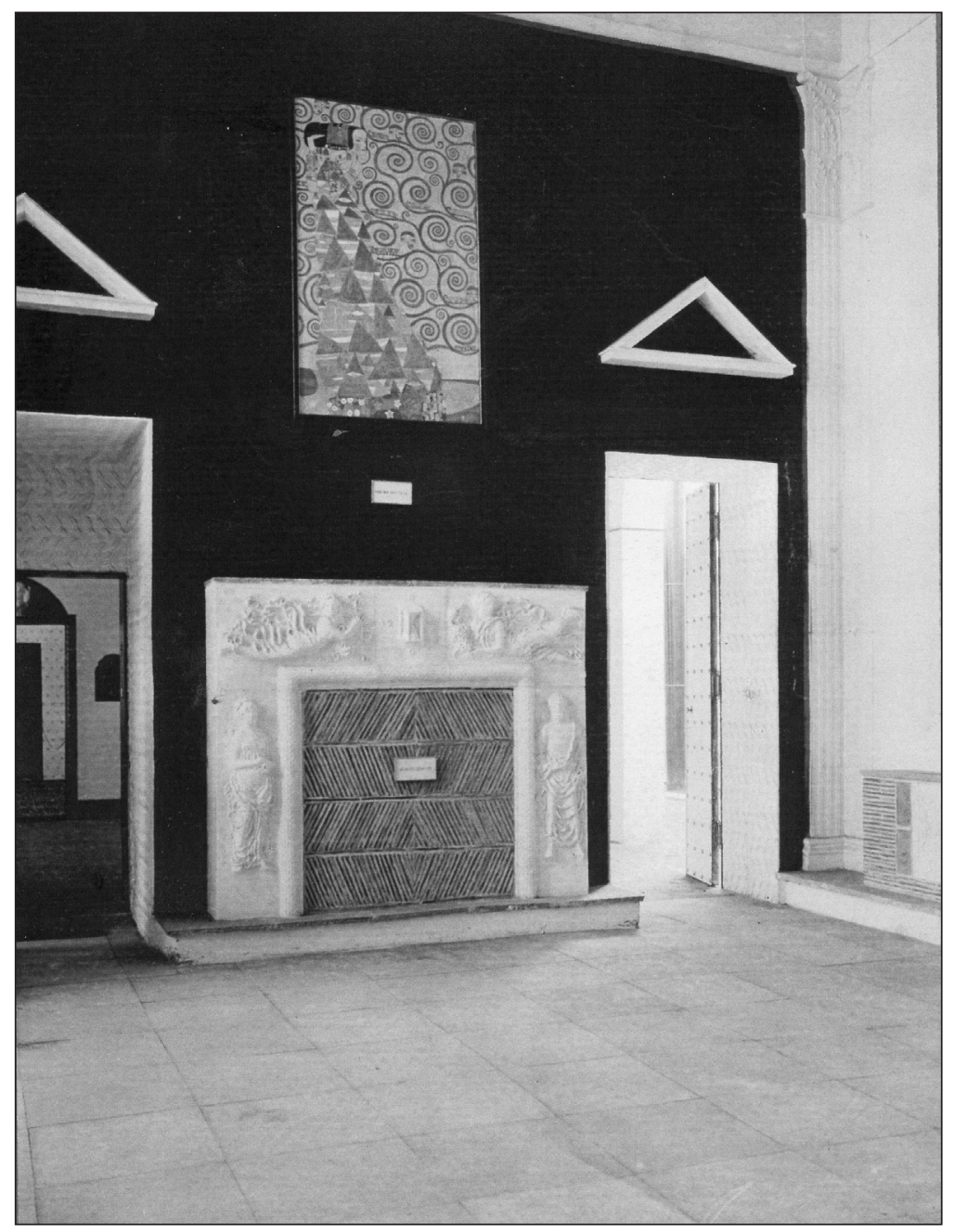

Figure 9: Oskar Strnad, interiors of the Austrian Pavilion for the Werkbund Ausstellung, Cologne 1914 (MAK V.S. 431 K.I. 13.820/7). Photo: (C MAK - Museum für angewandte Kunst, Vienna.

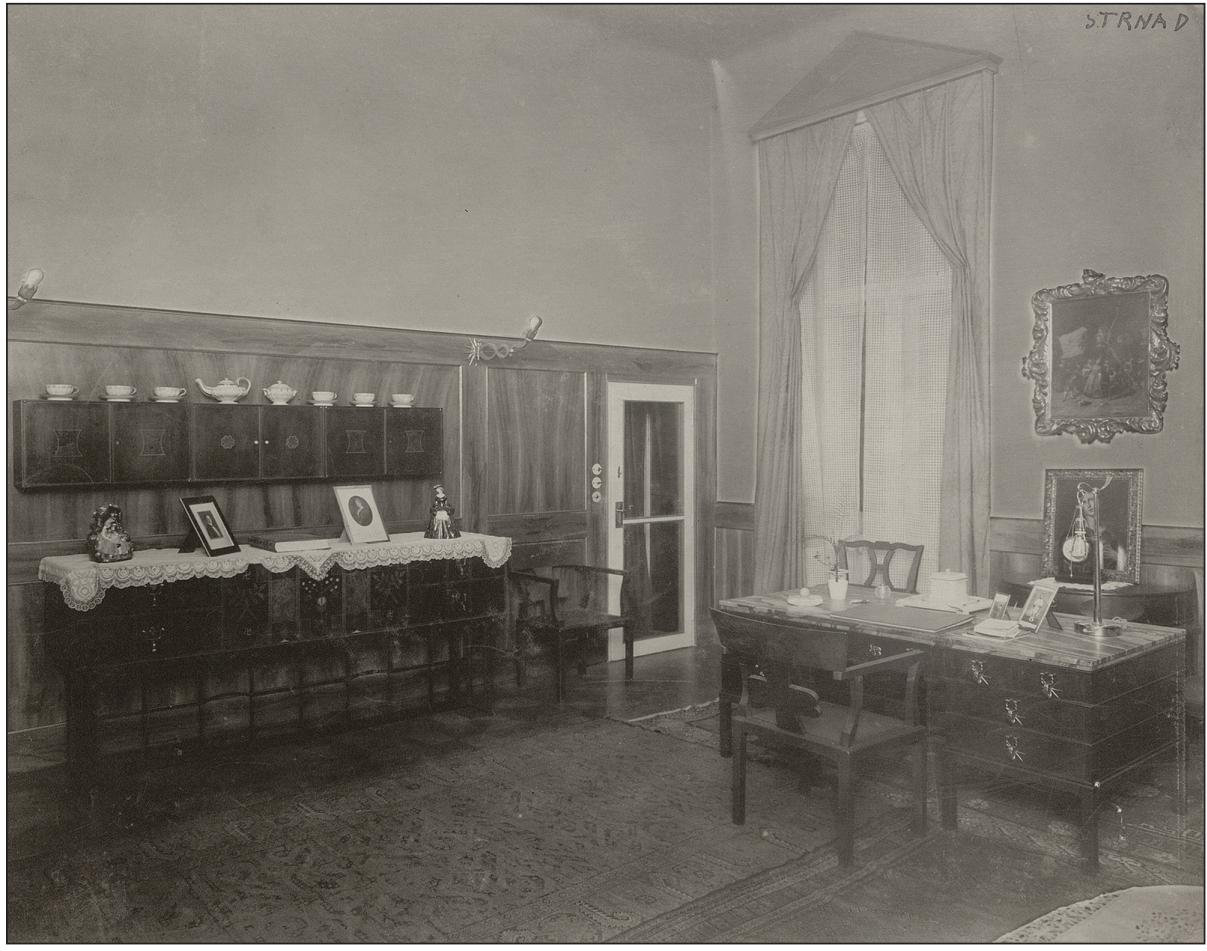

Figure 10: Oskar Strnad, Apartment Hellmann, Vienna, 1914 (MAK V.S.430, K.I. 13. 826/11). Photo: (c MAK - Museum für angewandte Kunst, Vienna. 


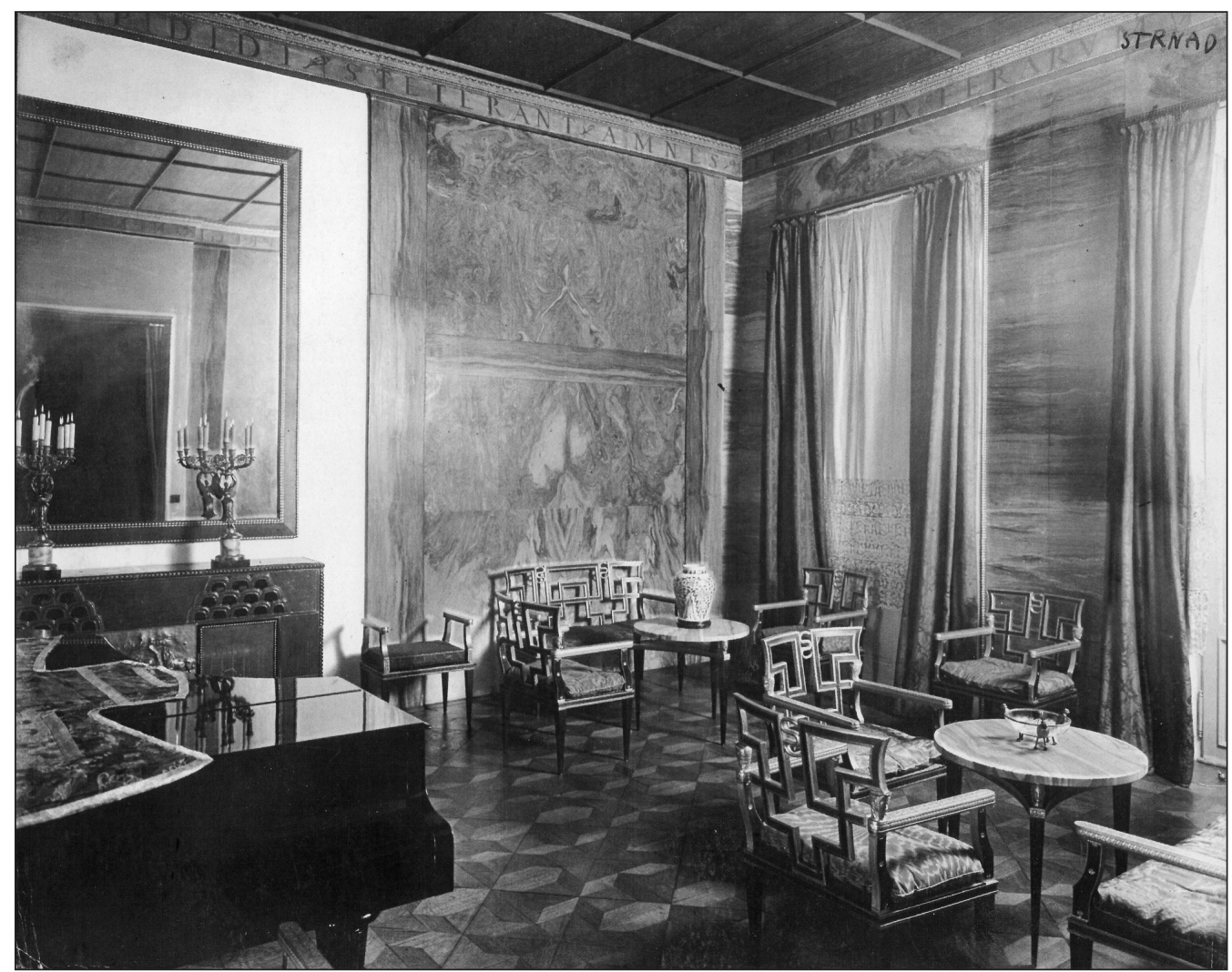

Figure 11: Oskar Strnad, Hellmann Apartment, Vienna, 1914 (MAK V.S. 430 K.I. 13.826/8). Photo: @ MAK - Museum für angewandte Kunst, Vienna.

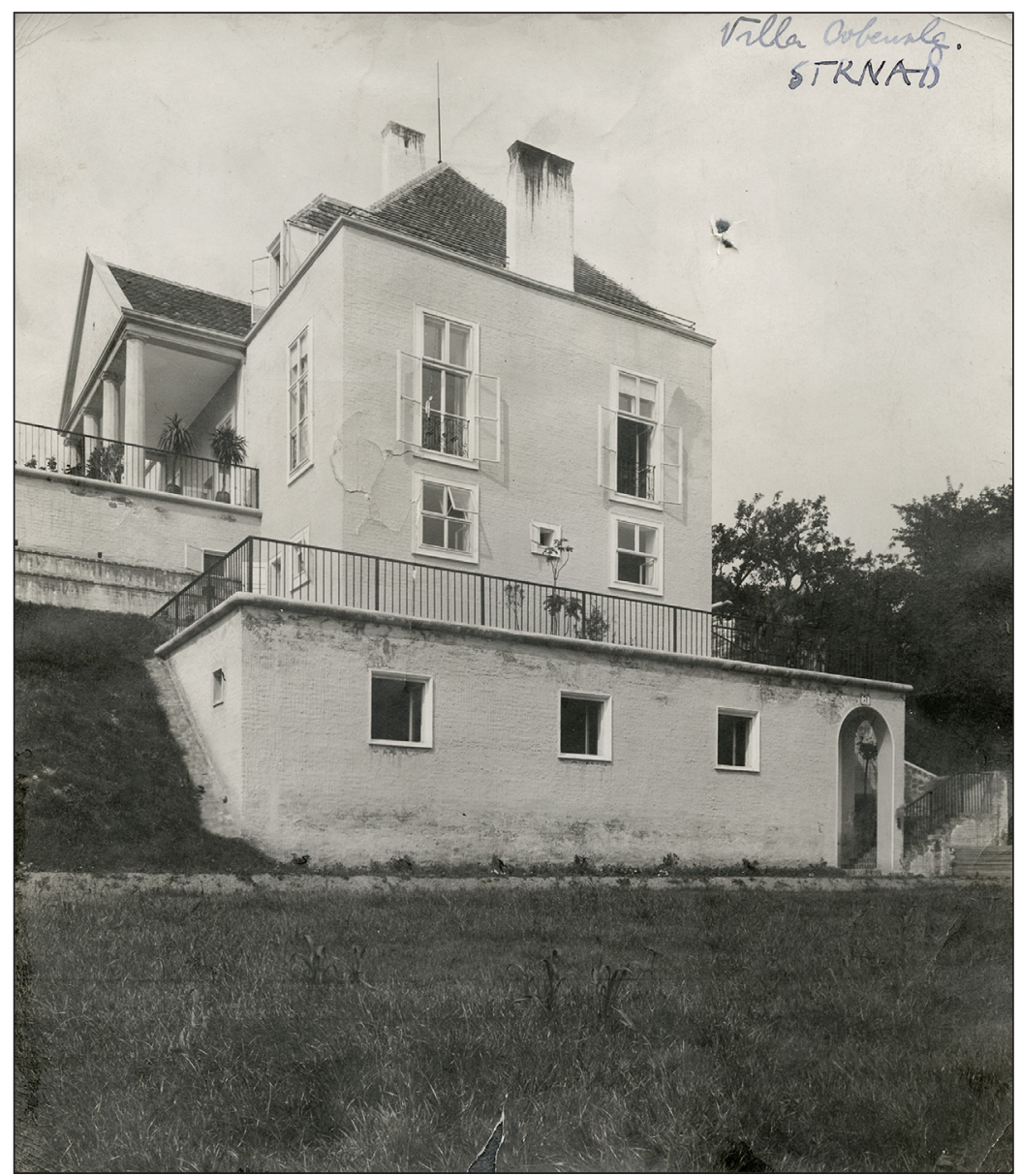

Figure 12: Oskar Strnad (Viktor Lurje, Oskar Wlach), Haus Hoch, Wien 19, 1912-14, Der Architekt, 29 (1913): tav. 131 (MAK V.S. 430 KI 13849/4). Photo: @ MAK - Museum für angewandte Kunst, Vienna. 


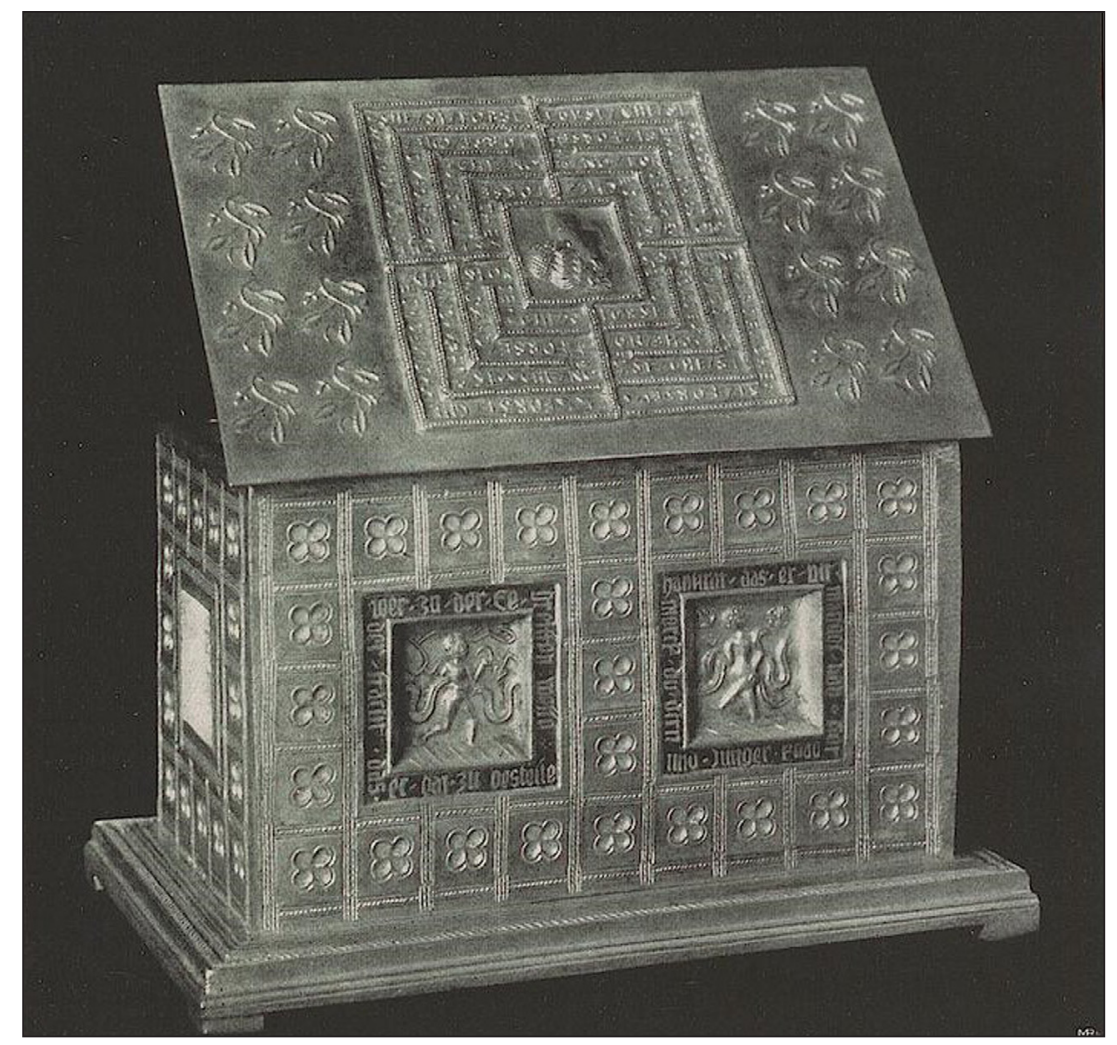

Figure 13: Viktor Lurje, bronze box for the Wiener Werkstätte. An inscription in Italian set within the labyrinth on the lid reads 'forse che sì forse che no', 'maybe yes, maybe no', a direct quote of the early 16th-century coffered ceiling of the Stanza del Labirinto in the Palazzo ducale of Mantua. From Steinmetz (1921: 192).

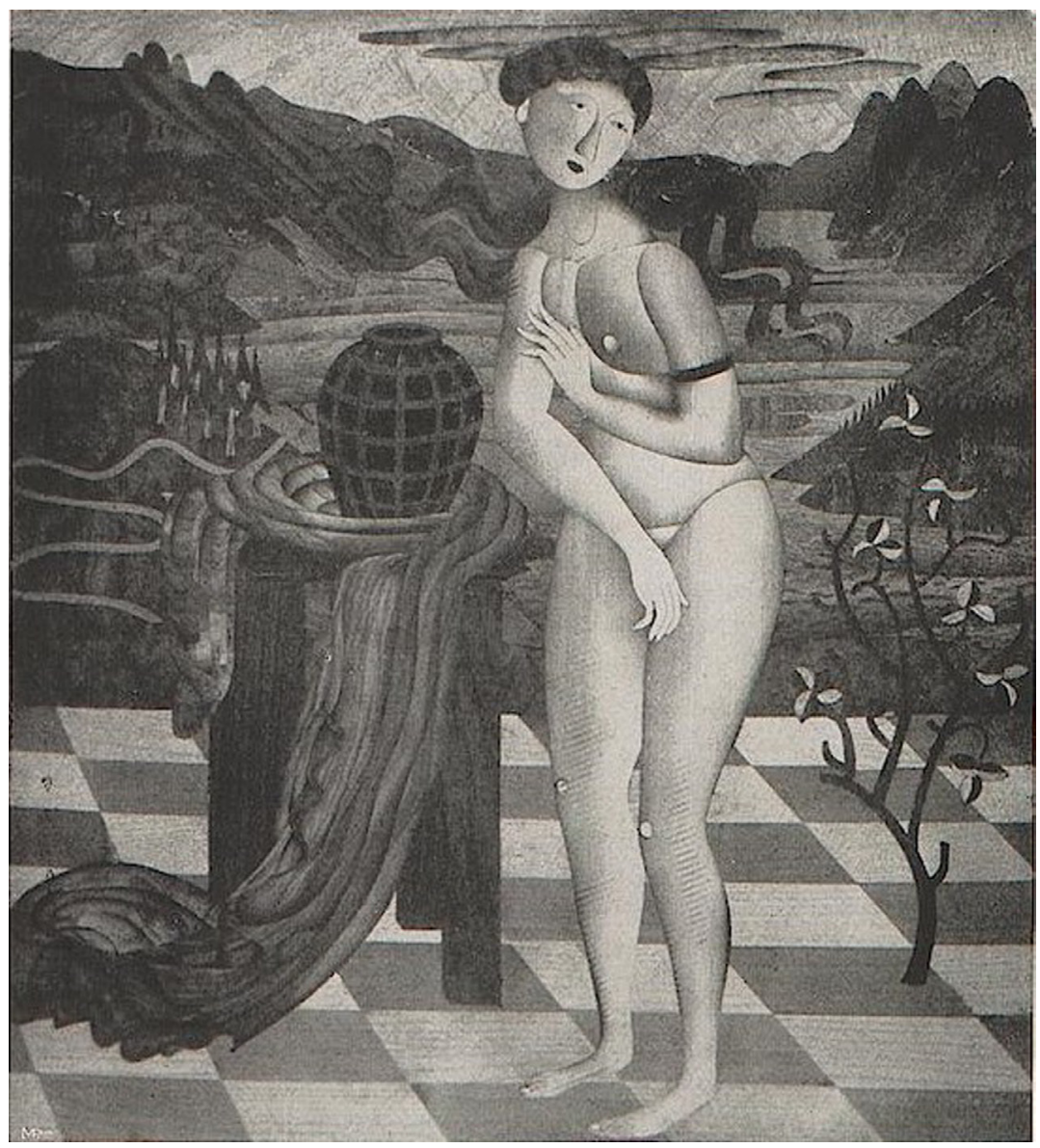

Figure 14: Viktor Lurje, inlaid work for the Wiener Werkstätte. The figure is a venus pudica. From Steinmetz (1921: 187). Original at Universität für angewandte Kunst, Collection and Archive, Inv. No.1677/0. 


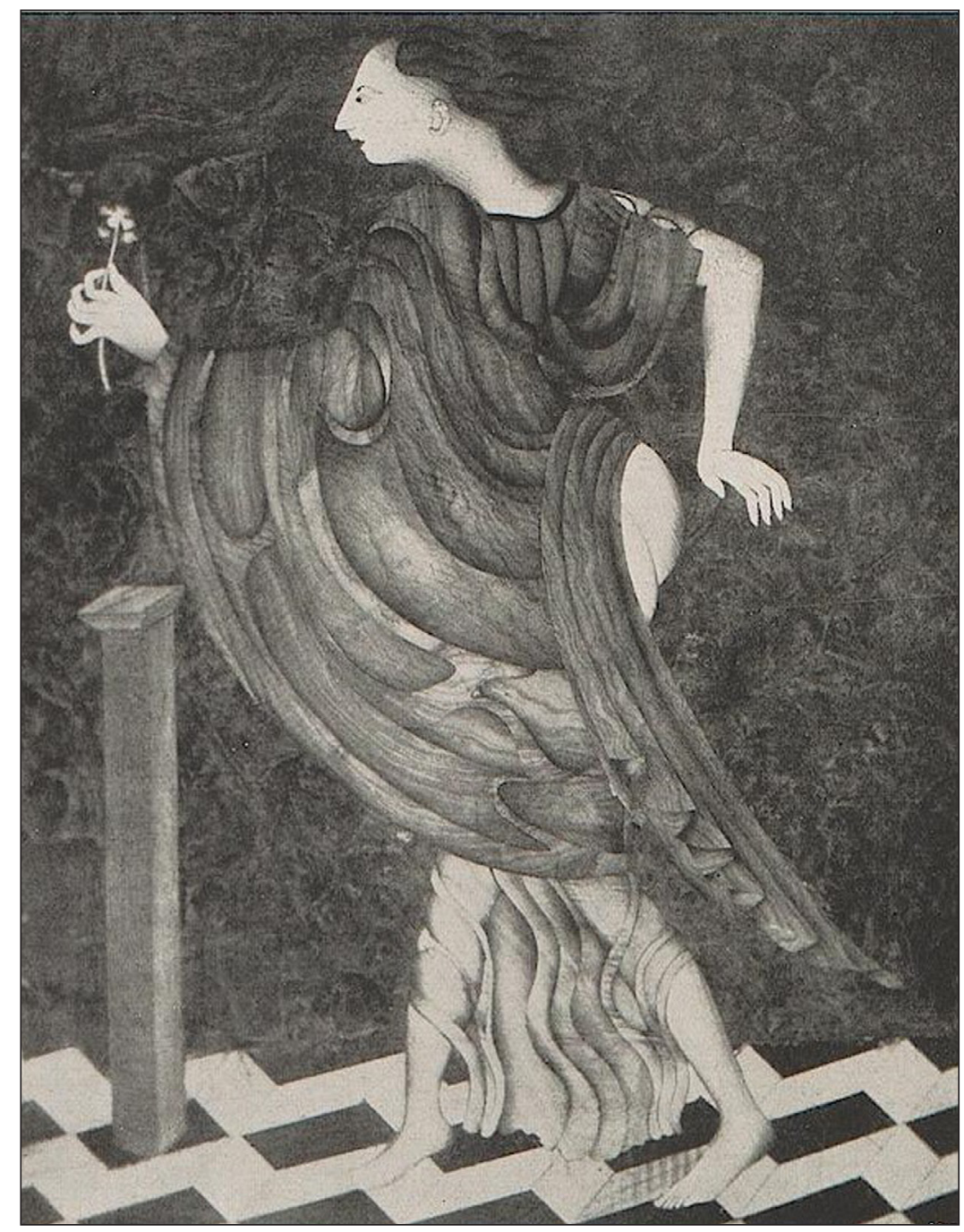

Figure 15: Viktor Lurje, inlaid work for a Wiener Werkstätte cabinet. The figure is the personification of hope, spes. From Steinmetz (1921: 195). Original at Universität für angewandte Kunst Vienna, Collection and Archive, Inv. No.1677/O.

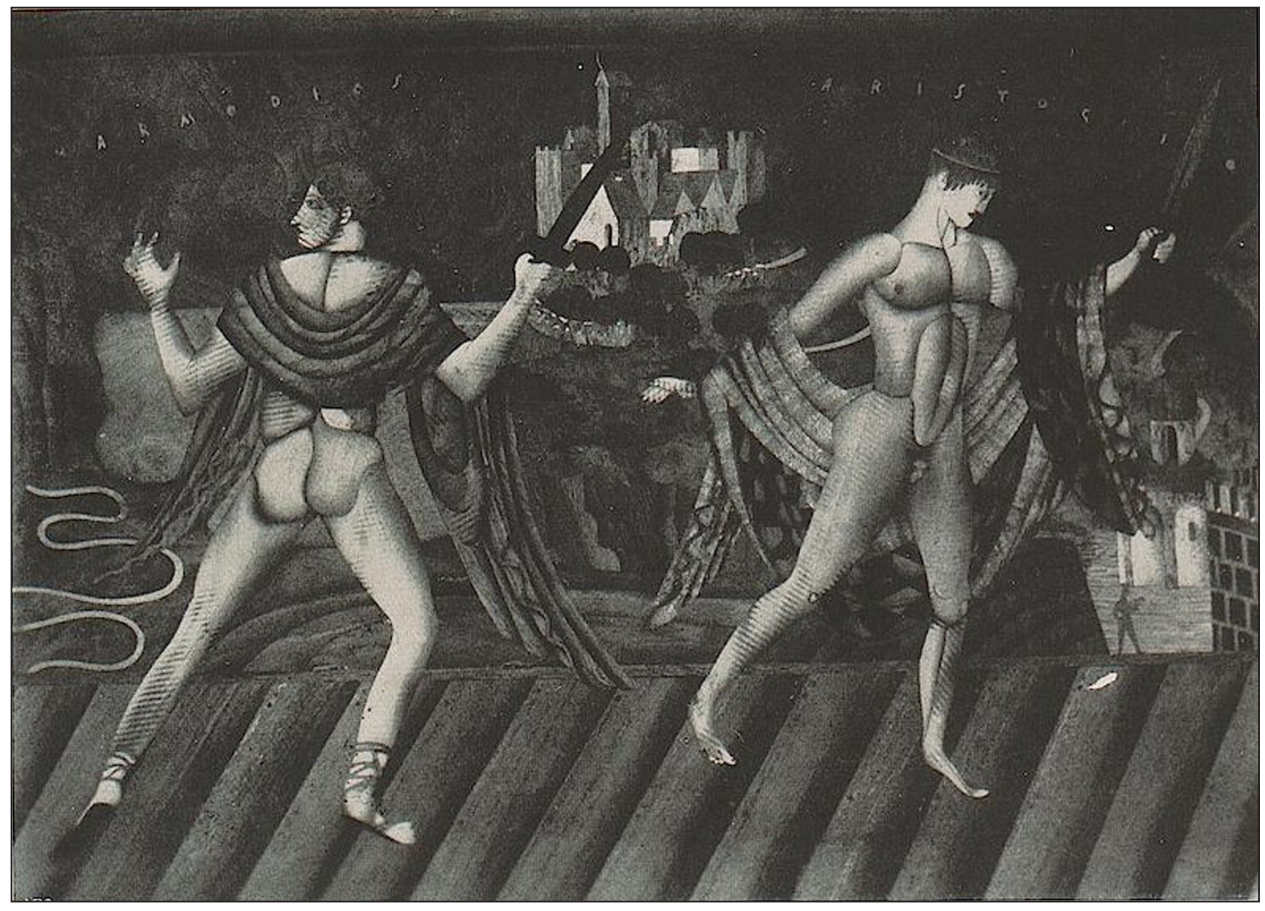

Figure 16: Viktor Lurje, inlaid work for the Wiener Werkstätte. The figures are Harmodius and Aristogeiton. From Steinmetz (1921: 198). 


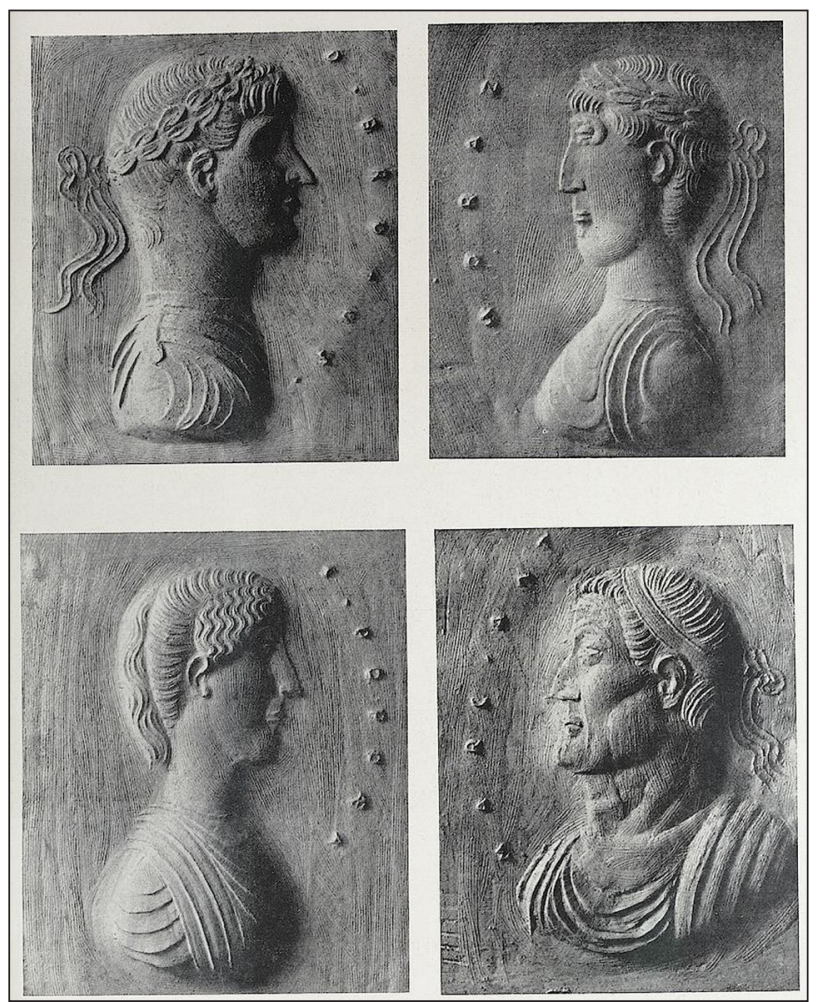

Figure 17: Viktor Lurje, stucco medals in the Antikensaal of Kassel Museum. From R (1923: 283).

In his works before WWI, Frank also appears to be interested in the technique of intarsia and more specifically in tarsie prospettiche, Italian Quattrocento inlaid works after a perspective schema (Wlach 1912: 44). To attain a visual effect similar to that of the tarsie on a cabinet for the Tedesko apartment, Frank simulated an inlaid labyrinth with painting (Wlach 1912: 42; Ott-Wodni 2015: M-WV 13) (Figure 5). In another cabinet for the same apartment, designed by Frank and realised by Leopold Spitzer, the doors show an inlaid schematic architectural structure - a chessboard floor represented in a strong accelerated perspective, with pilasters bearing a linear pediment - that directly recalls the tarsie prospettiche (Wlach 1912: 42 and 45; Ott-Wodni 2015: M-WV 5, 17, 20, 21, 22; Hackenschmidt 2016) (Figure 18).

\section{Architecture as Symbol: 'Humane' Architecture and Mediocritas}

In the 1920s, Lurje's and Strnad's affinity for highly intellectualised references to the classical world does not correspond to a similar search in Frank's work (Figures 19 and 20). After WWI, in fact, vague hints to the classical world might be found only in a sort of Mediterranean atmosphere that characterises some unrealised projects between 1926 and 1928, such as a 'Siedlung mit PatioHäusern', a 'Wohnhaus für Salzburg', a 'Wohnhaus für Wien XIII', and a series of US projects (Welzig 1998: 100, 121, 125, 191-97; Long 2002: 132, 136, 140-41). All these sketches are articulated around a central court that could be read as an impluvium.

Without the richness of erudite classical quotes and without overt reference to a written tradition, Frank's

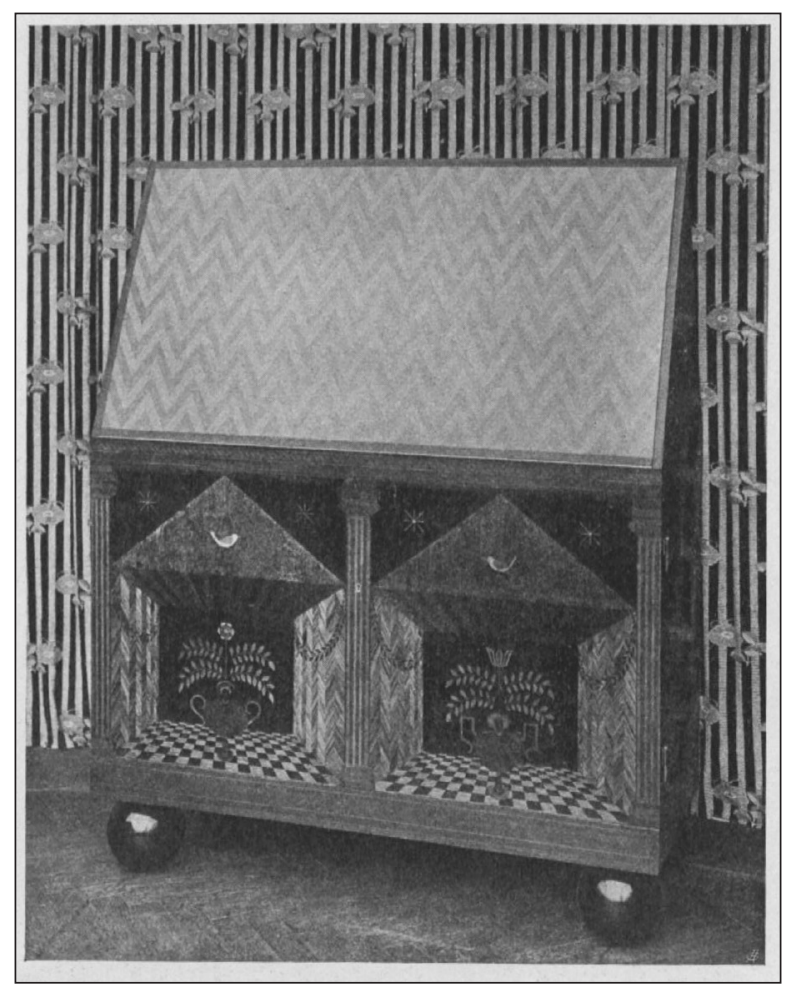

Figure 18: Josef Frank, cabinet with intarsia, realised by Leopold Spitzer. From Fischel (1911: 621). Photo: (c) MAK - Museum für angewandte Kunst, Vienna.

interest in classical imagery during the 1920s is apparently limited to these Mediterranean hints and to the use of proportional schemes, which indicate a more conventional reception of classical tradition (Payne 1994; Benelli 2015; Cohen 2014). Frank's interest in proportional questions was documented during his years at the $\mathrm{TH}$. The entire generation of architects working in the interwar period was in fact educated on texts such as Geschichte der Renaissance in Italien by Jakob Burckhardt and Renaissance und Barock by Heinrich Wölfflin, in which the clarity of Renaissance architecture relied on the use of crystalline proportional criteria (Payne 1994: 327). The study of proportional layouts in Frank's academic curriculum was also covered in the winter semester of 1904 and for the three years thereafter, in the course given by Hermann V. Heller, Die Lehre vom Bau und die Proportionen der menschlichen Figur, in which the teaching of architectural proportions was clearly linked with the study of the human body (Cardamone 2002: 17).

In Frank's writings after WWI, anthropometric proportioning constitutes a major theme. In Architektur als Symbol (1931), Frank describes Alberti's concinnitas, 'the requirement of total harmony between parts and whole', as 'one of our traditions that the laws of architecture derive from the human body' (Frank 1931b: 91). In the same year, Frank published a proportional grid, the scheme for the façade of Haus Beer, to illustrate an article reflecting on Alberti's architectural theories - namely the topos of the 'House [as] a little City' (Frank 1931a: 323; Leoni 1726: I, 11v and 79r; Cardamone 2016b: 30). Apart from the proportional schemes for Haus Beer and the illustrations for 


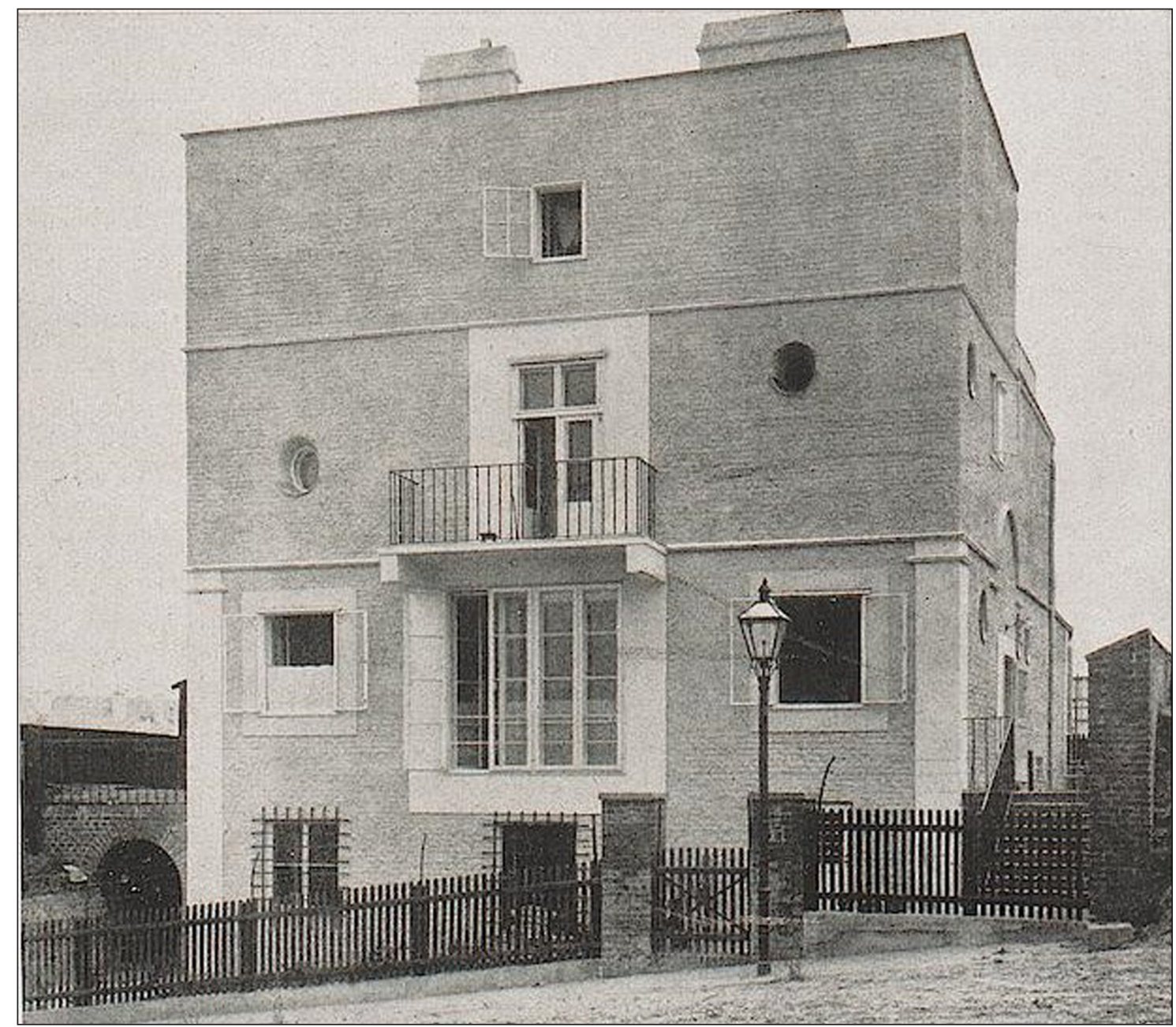

Figure 19: Josef Frank, Villa Scholl, Wien, 1913. From Frank (1919b: 418).

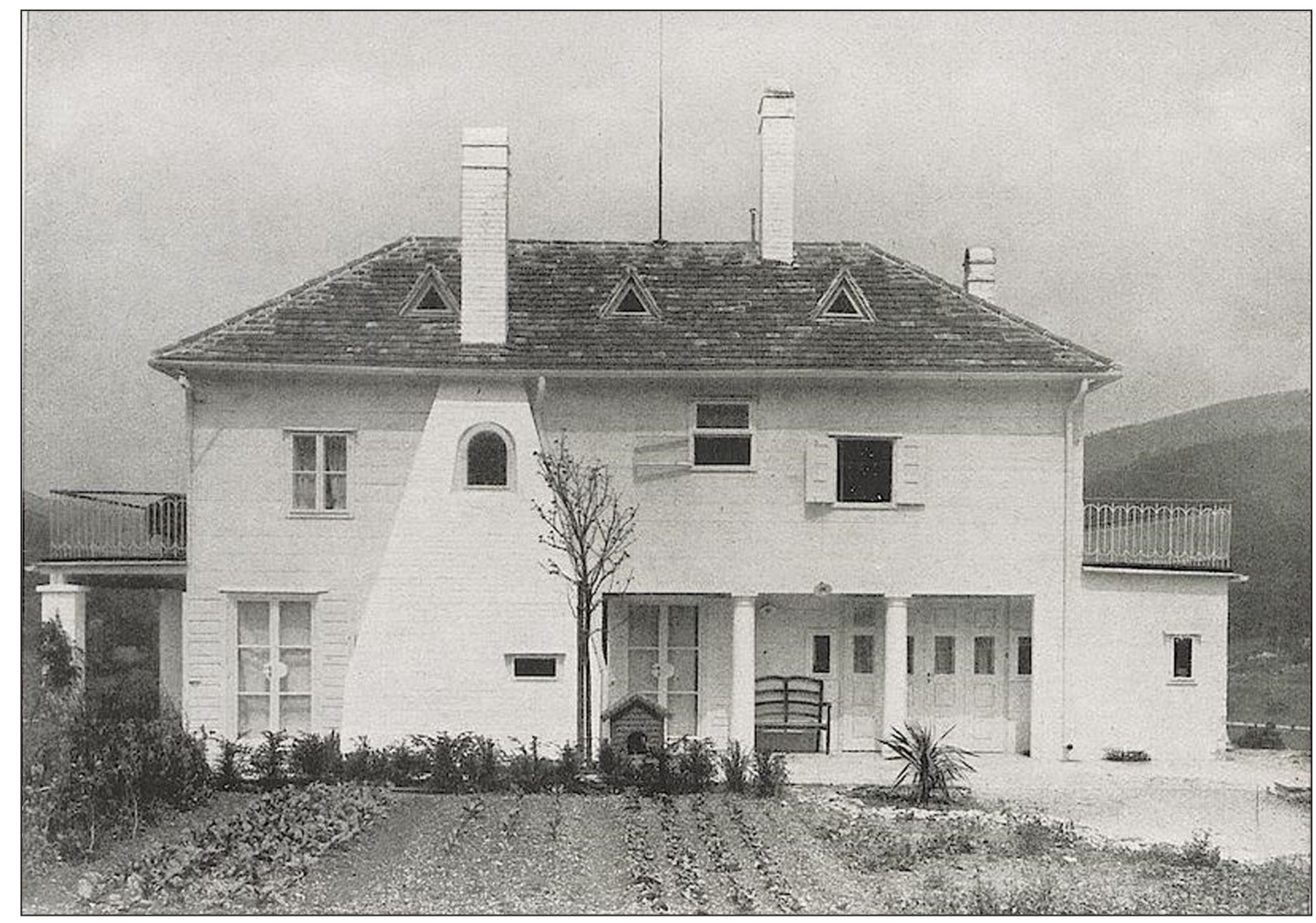

Figure 20: Josef Frank, Villa Bunzl, Ortman (Niederösterreich), 1914. From Frank (1919a: 411). 
'Rum och inredning' (Frank 1934), however, not much is known about Frank's effective use of proportional grids in his design process.

The topic of Frank's thorough use of proportional rules is controversial. While Sobotka is our principal source of information for Frank's use of proportional schemes, his interpretation is not neutral, which complicates our reading of Frank's intentions. Some well-known passages of the correspondence between Frank and Sobotka seem to emphasise the importance of proportional layout in Frank's design. But in Frank's writings, a proportional scheme is primarily a means to simply attain a standard result; no proportional system is presented as an actual model (Frank to Sobotka, 17 March 1963, Sobotka 1970: 279-80). Frank dealt with this topic earlier, in Architektur als Symbol, where in a passage about concinnitas he makes a controversial statement about the arbitrariness of Renaissance proportional norms (Frank 1931b: 91) and about the potential codification of concinnitas into rules to be applied in the 'building trade in such a way that [its] products remain acceptable' (Frank 1931b: 91).

Although he frequently writes about proportion, his interest in the classical world goes well beyond that aspect. His writings show elements of originality in his adhesion to classical thought. For Frank, classical tradition means above all an anthropocentrism with multiple facets: mediocritas, varietas and Annehmlichkeit. In Architektur als Symbol, he reflects comprehensively, if not linearly, on these seminal Renaissance categories, which he had first approached in the writing of his doctoral dissertation.

Frank's anthropocentrism, his focus on man, is not to be exclusively understood as the search for a non-mutable 'meter', for norms or ratios of classical origin. This 'meter', which is man, is in fact one of the most complex categories in Frank's theoretical work. In Architektur als Symbol, this is most evident in a passage in which Frank quotes Homer. Achilles, in Hades, confesses to prefer one single day of life spent 'to serve as the hireling of another ... rather than to be the lord over all the dead that have perished' (Frank 1931b: 49). The living man, with his imperfections, becomes the centre of Frank's 'humane architecture'.

The 'absolute standard' of an ideal concept of man is in fact mitigated, in Frank's writings, by the imperfections of a living man:

But in addition to the concept of man we also have the concept of the beautiful man, which need not be - and indeed is not - universally valid, for the normal human type does not correspond to this concept. We see in all people - this is instinct or tradition - an imperfect intention of nature, an imperfect striving towards one or more forms that are not universal, an average of all people; the beautiful man is he who has not remained the same in all times, once the aim of life that we seek again today. (Frank 1931b: 51)

Frank's reflection on man is part of a rethinking of the classical category of mediocritas, as it emerges in Frank's Architektur als Symbol. In his essay, the first meaning of the notion is obviously that of 'middle ground'; the Greek ideal of beauty was a Mittelding, 'a happy medium [between] two extremes' (Frank 1931b: 51), and various passages of Architektur als Symbol emphasise Mittelwerte (Cardamone 2002: 287-303; Frank 1931b: 48-54, 70-72). In some passages, mediocritas can also be understood as an attitude, a consistent search for middle values in contrast to the striving towards a single goal of the German Neues Bauen that Frank calls 'pathos': 'the understandable uncertainty of our time, coupled with the addiction to setting records, hardly permits the audacity to pursue such a middle ground to emerge, even though everyone knows that all our contentment can only move within an even middle ground' (Frank 1931b: 51; also 165, 167).

As an 'imperfect intention of nature' and a 'mediocre' measure of the world, man with his middle values obstructs the attainment of the goals to which German modern architecture aspires:

Alas, very few people accept that a pleasant life is always a via media [Mittelweg] between all kinds of ideals ... and that shaping a pleasant life as a composite of all these ideals is a matter with goals just as consistent and absolute as the goals of those who strive for a single extreme. The fate of modern architecture hinges on achieving this ambition. (Frank 1931b: 27-29)

The symbolisation of this 'mediocre' life needs Sentimentalität and Gschnass, sentimentality and frippery, of which Frank wrote in 1927 in the exhibition catalogue of the Weissenhofsiedlung (Frank 1927b).

As mediocritas is the direct answer to the ambitious goals of the Neues Bauen, varietas is one of the potential answers to the stylistic unity of modernity. In Frank's reading, every ambition of stylistic unity goes against the spirit of classical thought and implies an estrangement from reality. Frank pointed out that 'our tradition refers not to forms ... but rather to the fundamental concepts and principles that made man the centre of all things. And only those who realize this are capable of seeing and cultivating anew the endless diversity [Mannigfaltigkeit] within this Willen' (Frank 1931b: 61).

\section{Continuity of Thought}

'I do not think that I could renounce tradition, which does not mean that it consists in the imitation of the old', wrote Frank to Sobotka from Stockholm on 5 May 1966 (Sobotka 1970: 426). This neat distinction between a cultural tradition and a tradition of forms removes the apparent discrepancy between Frank's built work - which bears no trace of a conventional formal continuity - and his writings, which testify to a vivid reflection on history. This idea of continuity of thought, overtly expressed only late in his career, informs Frank's entire theoretical production. Like his reflection on proportion, it is a rather conventional approach to classical tradition, grounded in both Viennese and 19th-century contexts (Loos 1913; Karge 2016). During the 1920s, Frank's references to the unbroken continuity of classical tradition as a tradition of 
thought are implicit but consistent. Classical architecture possesses all characteristics his radical colleagues look for in vain, he says: it is modern, international and revolutionary (Brucculeri 2016: 26). This conviction constitutes the basis of his critique of contemporary tendencies.

In his writings, Frank refers to a generic 'classical' tradition whose historical models vary. At the beginning of the 1920s, the reference to a living tradition of Italian Renaissance gives Frank the necessary detachment to observe and comment on the formal experiments of Hoffmann's followers (Frank 1921-22: 167); some years later, in an excursus about Viennese modern architecture, it is Viennese Baroque, with its status of a universally comprehensible tradition, that limits the formal research of the Werkbund. He writes that 'in a supranational land made up of peoples with the most varied cultural backgrounds' it is understandable that forms 'that are universally comprehensible, namely those of antiquity, were sought out time and again. This corresponds with the intentions of all modern architecture after 1918' (Frank 1926: 269).

From the last years of the 1920s to the beginning of the following decade, Frank examines the internationality and modernity of the classical tradition in depth. In 1927, he noted, 'International architecture has always existed. It was the architecture of the most developed civilisation whose people were able to pass their architecture on to other cultures. ... Since all people have adopted classical culture, classical culture has become international' (Frank 1927a: 335). Written during the polemical climate fuelled by the Weissenhofsiedlung exhibition, this passage shows to what extent classical tradition informed Frank's reading of modernity and was intended as a reaction to contemporary architectural research. In Frank's view, the classical is also the only 'style' of all revolutionary and mechanical eras because 'Revolutionen führen zur Antike' - revolutions lead cultures back to antiquity in their cyclic revival (Frank 1931b: 94).

The many references to antiquity and its renaissances are based on a strong ideological approach in Frank's writings. This is most evident in Architektur als Symbol (1931), in which the history of architecture is rewritten to intervene in contemporary discourse (Tafuri 1969; Scalvini Sandri 1984; Tournikiotis 1999; Van Eck 2004). Frank's purpose is to affirm that Austria's architectural culture belongs to an unbroken continuity of the classical tradition, unlike German architecture - both historical and modern - which is excluded from that tradition (Frank 1931b: 76-77 or 98-99). According to Frank, modern architecture was born either in the 8th century $\mathrm{BC}$, when the first Doric column was erected, giving an anthropomorphic shape to the material (Frank 1931b: 34; Sobotka 1970: 243), or in 1420, "the first time an architect declared: "from now on I shall build in the modern style"' (Frank 1927a: 319). In this unbroken continuity, 'machines are products and essential outcomes of the intellectual trajectory of the ancients, who made man the focus of all thought and the measure of all things' (Frank 1931b: 137). The corollary of this continuity is that, even at the beginning of the 1930s, Frank saw no contradiction between the use of a historical architectural language and the comfort and functionality of modern needs (Museum of Modern Art 1932):

It is entirely mistaken to believe that the machine age has created a new spirit, because this goal has always been sought, and to anyone who understands the full context, everything that has been created in Europe since the earliest days comes together wonderfully into a total image, without his sense for harmony compelling him to sit in a tubular steel chair because he has a bathtub. (Frank 1931b: 151-53)

\section{Conclusion}

It is only in the latest phase of his career, at the beginning of the 1960s, in the context of a considerably different approach to modernity, that Frank admits the biographical relevance of classical tradition: 'lately I have ever more inclination towards classical culture, for I think that the abandonment of this tradition has caused much evil' (Frank to Sobotka, Stockholm 18 November 1961, Sobotka 1970: 397). One could certainly argue that Frank was now simply joining the chorus of the prevailing critics of the modern movement. At the beginning of the 1960s, furthermore, in the prevailing historiographical approach, Frank stood on the margins of the architectural debate (Welzig 1998: 211-12).

These late statements confirm a lifelong and to some extent contradictory search for the meaning of classical tradition. Open to varietas and mediocritas, Frank's 'optimistic' rethinking of classical tradition is a search for the basis of a true modern 'humane' architecture (Wlach 1912: 43; Frank post 1945?b: f. 28). Frank's anthropocentrism, based on man as the imperfect and relative meter of the world, constitutes his most original contribution to the interwar reception of classical tradition. The concluding lines of Architektur als Symbol, using a literary classical topos, provide insight into this anthropocentrism: 'Men are alike and yet all different from one another. The leaves of a tree are like each other, but we can never find two that are perfectly identical' (Frank 1931b: 181). While the presence of Alberti is indisputable in Frank's reference to varietas and concinnitas (Frank 1931b: 183), it is only implicit, having been strongly adapted to the contemporary discourse.

Frank's originality vis à vis his Viennese contemporaries in his reception of antiquity and the Renaissance emerges on different levels. In his work, classical categories are not separate objects of reflection but rather tightly linked to his thoughts on modernity. In the more general context of classical reception in Europe during the 1920s and the 1930s, Frank's attention to varietas and mediocritas proved to be of the greatest originality. Frank's path to antiquity and the Renaissance, inaugurated by his doctoral thesis, can lead researchers to examine the multiple facets of the reception of classical architecture in the 20th century, beyond searches for immutable norms, for Mediterranean purism or for authoritative references to antique monumentality with an ambiguous cultural background. 


\section{Notes}

${ }^{1}$ A first outline of Mayreder's academic curriculum is in Cardamone (2002: 350-53), based on the Archiv Technische Universität (TU), Personalakt Mayreder Karl 797; further biographical elements are in Architektenlexikon of the Architekturzentrum Wien, http://www. architektenlexikon.at/de/395.htm (accessed January 2019); on Mayreder as urban planner, see Jager (2018).

2 For Max Theuer thesis, see Rigorosen-Journal 2(4) (ex 1911/12), available in the Archiv TU. König, Theuer's supervisor together with Josef Neuwirth, is explicitly mentioned in Alberti (1912: xxii-xxiii).

${ }^{3}$ The original is in the Archiv TU Wien, $304-1909 / 10$.

${ }^{4}$ Archiv TU Wien, P.A. Fabiani, Diensttabelle No. 381, Blatt 2, curriculum Juli 1916.

${ }^{5}$ Archiv TU Wien, P.A. Fabiani, 'an das hochlöbliche Rektorat der k.k. Technischen Hochschule in Wien', 16 March 1918, f. 1.

${ }^{6}$ For the use of a strigilatum frieze in the Viennese context in which Frank operated, see the work of Oskar Strnad, above all a funerary monument dated 1908, photo MAK, V.S. 431, K.I. 13.841/7-8 or the Gartenhalle in the Frühjahrausstellung at the ÖMfKI 1912.

7 A Doric order is also used in Strnad's villa for Dr Kranz in Raack, 1913, and in Strnad's kleiner Vortragssaal of the Urania, 1915, in collaboration with Wlach and Frank (Meder and Fuks 2007: 141).

${ }^{8}$ For biographical details on Lurje, see Cardamone (2002: 197-98) and now in Architektenlexikon of the Architekturzentrum Wien, http://www.architektenlexikon.at/de/1437.htm (accessed February 2019) and Prokop (2016). An introduction to Lurje's knowledge of antique and Renaissance iconography is in Cardamone (2002: 183-204).

\section{Competing Interests}

The author has no competing interests to declare.

\section{References}

\section{Unpublished Sources}

Frank, J. post 1945?a. 2. Aesthetische Weltanschauung. Unpublished manuscript (end of the 1940s/beginning of the following decade, post 1945): archive Hermann Czech Vienna.

Frank, J. post 1945?b. 4. Kunst und Gesellschaft. Unpublished manuscript (end of the 1940s/beginning of the following decade, post 1945): archive Hermann Czech Vienna.

Sobotka, W. 1970. Principles of Design. Unpublished typescript, New York: Avery Library.

Strnad, 0. 1904. Das Prinzip der Dekoration der fruechristlichen Kunst. Eine kritische Studie ihrer toreutischen Stereotomie mit besonderer Ruecksichtnahme der bezueglichen Werke Roms und Ravenna. Unpublished doctoral thesis, Technische Hochschule Wien. Archiv TU Wien 2/093 - 1901/11.

Wlach, 0. 1906. Die farbige Inkrustation in der Florentiner Protorenaissance. Eine Studie über die Verwendung der Farbe in Architektur. Unpublished doctoral dissertation, Technische Hochschule Wien. Archiv TU, 2/148 - 1901-11.

\section{Published Sources}

Abhandlungen. 1955. Abhandlungen des Österreichischen Dokumentationszentrum für Technik und Wissenschaft. Vol. 26. Wien: Österreichisches Dokumentationszentrum für Technik und Wirtschaft.

Alberti, LB. 1541. De Re Aedificatoria Libri Decem Leonis Baptistae Alberti Florentini [...] quibus omnem Architectandi rationem dilucida breuitate complexus est [...]. Argentorati: Jakob Cammerlander.

Alberti, LB. 1912. Leon Battista Alberti Zehn Bücher über die Baukunst ins Deutsche übertragen eingeleitet und mit Anmerkungen und Zeichnungen versehen durch Max Theuer. Wien und Leipzig: Heller.

Benelli, F. 2015. Rudolf Wittkower versus Le Corbusier. A Matter of Proportion. Architectural Histories, 3(1): 8. DOI: https://doi.org/10.5334/ah.ck

Brinkmann, B. 2003. Varietas und Veritas. Normen und Normativität in der Zeit der Renaissance. Castiglione's Libro del Cortegiano. München: Wilhelm Fink Verlag.

Brucculeri, A. 2016. Renaissance italienne et architecture au XIXe siècle. Une introduction. In: Brucculeri, A and Frommel, S (eds.), Renaissance italienne et architecture au XIXe siècle. Interprétations et restitutions, 11-32. Rome: Campisano.

Brucculeri, A and Frommel, S. (eds.). 2016. Renaissance italienne et architecture au XIXe siècle. Interprétations et restitutions. Rome: Campisano.

Burckhardt, J. 1868. Geschichte der Renaissance in Italien. Stuttgart: Verlag von Ebner $\&$ Seubert.

Cardamone, C. 2002. La tradizione classica negli scritti di architettura di Josef Frank. Unpublished thesis (PhD), Università degli Studi di Firenze.

Cardamone, C. 2005. Gli architetti austriaci e l'Italia intorno al 1900. Storia dell'urbanistica. Toscana (Architetti in viaggio, suggestioni e immagini), 11: 93-114.

Cardamone, C. 2006. Schede $n^{\circ}$ 65-67, 83, 94, 98. In: Morolli, G and Acidini, C (eds.), L'uomo del Rinascimento. Leon Battista Alberti e le arti a Firenze tra ragione e bellezza, 186-88, 214-15, 264, 269-270. Firenze: Mandragora.

Cardamone, C. 2016a. Josef Frank and the History of Architecture. Gothic and the Renaissance, Leon Battista Alberti and Albrecht Dürer in Architectural Discourse on Neues Bauen at the Beginning of the 1930s. Journal of Art Historiography, 14 (June 2016). https:// arthistoriography.files.wordpress.com/2016/05/cardamone.pdf

Cardamone, C. 2016b. Frank and Alberti. The Reception of De re aedificatoria in Josef Frank's Writings. In: von Thun-Hohenstein, C, Czech, $\mathrm{H}$ and Hackenschmidt, S (eds.), Josef Frank. Against Design. Das anti-formalistische Werk des Architekten, 30-39. Basel: Birkhäuser.

Cardamone, C. 2018. Josef Frank: Leon Battista Alberti a Vienna 1900. In: Cardamone, C (ed.), Josef Frank, L'architettura religiosa di Leon Battista Alberti, 84-97. Milano: Electa.

Cardamone, $\mathbf{C}$ and Torello, F. forthcoming. Renaissance oder Barock? Architectural Historiography in the Pedagogy of the Technische Hochschule in Vienna, 1875-1913. 
Cohen, MA. 2014. Conclusion: Ten Principles for the Study of Proportional Systems in the History of Architecture. Architectural Histories, 2(1): 7. DOI: https://doi.org/10.5334/ah.bw

Czech, H. 1986. Ein Begriffsraster zur aktuellen Interpretation Josef Franks. Um Bau, 10 (August 1986): 105-20. In: Meder, I (ed.), Josef Frank. Eine Moderne der Unordnung. Salzburg - Wien - München: Verlag Anton Pustet, 2008.

Dvořák, M. 1927. Geschichte der italienischen Kunst im Zeitalter der Renaissance. I. Das 14. und 15. Jahrhundert. München: Piper.

Fischel, H. 1911. Die Ausstellung österreichischer Kunstgewerbe im k. k. Österreichischen Museum. Kunst und Kunsthandwerk, 14(12): 617-673.

Frank, J. 1910. Ueber die urspruengliche Gestalt der kirchlichen Bauten des Leone Battista Alberti. Unpublished thesis (doctoral), Technische Hochschule Wien. Archiv TU, 304 - 1909/10. In: Bojankin, T, Long, C and Meder, I (eds.), Josef Frank. Schriften - Writings. Vol. 1. Veröffentliche Schriften, 47-119. Published Writings 1910-1930. Wien: Metroverlag, 2012.

Frank, J. 1919a. Das neuzeitliche Landhaus. Innendekoration, 30(12): 410-15.

Frank, J. 1919b. Die Einrichtung des Wohnzimmers. Innendekoration, 30(12): 416-19.

Frank, J. 1926. Wiens moderne Architektur bis 1914. Der Aufbau, 1 (8-9): 162-68. In: Bojankin, T, Long, C and Meder, I (eds.), Josef Frank. Schriften - Writings. Vol. 1, Veröffentliche Schriften. Published Writings 1910-1930, 268-277. Wien: Metroverlag, 2012.

Frank, J. 1927a. Vom neuen Stil. Ein Interview von Josef Frank. Baukunst, 3(8): 234-249. In: Bojankin, T, Long, C and Meder, I (eds.), Josef Frank. Schriften - Writings. Vol. 1, Veröffentliche Schriften. Published Writings 1910-1930, 318-35. Wien: Metroverlag, 2012.

Frank, J. 1927b. Der Gschnas fürs G'mut und des Gschnas als Problem. In: Bau und Wohnung, Stuttgart: Akademischer Verlag Dr. Fr. Wedekind \& Co. pp. 48-57. In: Bojankin, T, Long, C and Meder, I (eds.), Josef Frank. Schriften - Writings. Vol. 1, Veröffentliche Schriften. Published Writings 1910-1930, 288-299. Wien: Metroverlag, 2012.

Frank, J. 1931a. Das Haus als Weg und Platz. Baumeister, 29(8): 316-23. In: Bojankin, T, Long, C and Meder, I (eds.). Josef Frank. Schriften - Writings. Vol. 2, Veröffentliche Schriften. Published Writings 1931-1965, 198-209. Wien: Metroverlag, 2012.

Frank, J. 1931b. Architektur als Symbol. Elemente deutschen neuen Bauens. Wien: Schroll. In: Bojankin, T, Long, C and Meder, I (eds.). Josef Frank. Schriften - Writings. Vol. 2, Veröffentliche Schriften. Published Writings 1931-1965, 9-191. Wien: Metroverlag, 2012.

Franz, R and Nierhaus, A. (eds.). 2007. Gottfried Semper und Wien. Die Wirkung des Architekten auf 'Wissenschaft, Industrie und Kunst'. Wien: Bölhau.

Gosebruch, M. 1957. 'Varietà' bei Leon Battista Alberti und der Wissenschaftliche Renaissancebegriff. Zeitschrift für Kunstgeschichte, 20(3): 229-238. DOI: https://doi.org/10.2307/1481354
Hackenschmidt, S. 2016. Handwerkliche Typisierung: Die Wiener Möbelkultur zwischen Tischlerkultur und Massenproduktion. In: von Thun-Hohenstein, C, Czech, $\mathrm{H}$ and Hackenschmidt, S (eds.), Josef Frank. Against Design. Das anti-formalistische Werk des Architekten, 172-83. Basel: Birkhäuser.

Hub, B. 2015. Oskar Wlachs Reise zur 'farbigen Incrustation in der Florentiner Protorenaissance' und die Wiener Moderne, paper presented at Sehnsuchtslos und postkanonisch? Architektenreisen nach Italien im 20. Jahrhundert. Rome: Bibliotheca Hertziana, 4-5 December.

Hvattum, M. 2004. Gottfried Semper and the Problem of Historicism. Cambridge: Cambridge University Press. DOI: https://doi.org/10.1017/CBO9780511497711

Jager, M. 2018. 'Regulierung' und Gestaltung der Großstadt. Karl Mayreder, Heinrich Goldemund und der Generalregulierungsplan für Wien. In: Jager, M and Sonne, W (eds.), Großstadt gestalten. Stadtbaumeister in Europa, 75-103. Berlin: DOM publishers.

Karge, H. 2016. Renaissance: mutations d'un concept et 'invention' d'un style dans la première moitié du XIXe siècle en France et en Allemagne. In: Brucculeri, A and Frommel, S (eds.), Renaissance italienne et architecture au XIXe siècle. Interprétations et restitutions, 35-54. Rome: Campisano.

Kirsch, K. 1987. Die Weissenhofsiedlung. Werkbund Ausstellung 'die Wohnung' - Stuttgart 1927. Stuttgart: Stuttgart Deutsche Verlags-Anstalt.

König, C. 1901. Rektorsrede, gehalten am 26. Oktober 1901. In: Bericht über die feierliche Inauguration des für das Studienjahr 1901/02 gewählten Rektors o. ö. Professors der Baukunst Carl König am 26. Oktober 1901, 42-63. Wien: Verlag der K. K. Technischen Hochschule.

König, C. 1904. Ein Schriftsteller, der oft ein treffendes Urteil in künstlerischen... In: Schulte, JA, Thumb, EE and Wlach, $\mathrm{O}$ (eds.), Wiener Türmer. Ein Almanach für das Jahr 1904, 5-7. Wien: Jacques Philippe.

Kristan, M. 1999. Carl König 1841-1915. Ein neubarocker Großstadtarchitekt in Wien. Wien: Holzhausen.

Leoni, G. 1726. Della architettura di Leon Battista Alberti libri X, della pittura libri III, della statua libro I. London: presso Tommaso Edlin.

Lexicon. 1984. Lexicon Iconographicum Mithologiae classicae. Vol. 2.1. Zurich and Munich: Artemis Verlag.

Lexicon. 1994. Lexicon Iconographicum Mithologiae classicae. Vol. 8. Zurich and Munich: Artemis Verlag.

Long, C. 2001. Carl König and Architectural Education at the Vienna Technische Hochschule, 1890-1913. Journal of Architectural Education, 55(1): 21-30. DOI: https://doi.org/10.1162/104648801753168783

Long, C. 2002. Josef Frank. Life and Work. Chicago and London: The University of Chicago Press.

Long, C. 2018. The Königsschule and Its Legacies. In Shapira, E (ed.), Design Dialogue: Jews, Culture and Viennese Modernism, 129-42. Wien: Böhlau. DOI: https://doi.org/10.7788/9783205208501.129

Loos, A. 1898. Die alte und die neue Richtung in der Baukunst. Der Architekt, 4: 31-32. In Opel, A (ed.), 1983. Adolf Loos. Die Potemkin'sche Stadt. Verschollene Schriften 1897-1933, 62-68. Wien: Prachner. 
Loos, A. 1913. Meine Bauschule. In Loos, A. 1931. Trotzdem, 64-67. Innsbruck: Brenner Verlag.

Loos, A. 1921. Ins Leere gesprochen. Berlin: Verlag der Sturm.

Marchand, SL. 1994. The Rhetoric of Artifacts and the Decline of Classical Humanism: The Case of Josef Strzygowski. History and Theory, 33(4): 106-30. DOI: https://doi.org/10.2307/2505504

Mayreder, K. 1915. Die Lehrkanzel für Architektonische Formenlehre, architektonisches Zeichnen und malerische Perspektive, Kollegium für Städtebau. In: Neuwirth, J (ed.), Die k.k. Technische Hochschule in Wien 1815-1915, 528-530. Wien: Selbstverlag der K.K. Technischen Hochschule.

Meder, I and Fuks, E. (eds.). 2007. Oskar Strnad 1879-1935. Salzburg und München: Verlag Anton Pustet.

Moravánszky, A. 1988. Die Architektur der Donaumonarchie 1867-1918. Budapest: Corvina.

Museum of Modern Art. 1932. Modern Architecture. International Exhibition. New York Feb. 10 to March 23, 1932. New York: The Museum of Modern Art.

Nerdinger, W and Oechslin, W. (ed.). 2003. Gottfried Semper, 1803-1879. Architektur und Wissenschaft. München: Prestel.

Oechslin, W. 2002a. Otto Wagner, Adolf Loos and the Road to Modern Architecture, Cambridge: Cambridge University Press. (First published: Oechslin, W. 1994. Stilhülse und Kern. Otto Wagner, Adolf Loos und der evolutionäre Weg zur modernen Architektur. Zürich: gta/Ernst und Sohn).

Oechslin, W. 2002b. Klassisch und modern: um 1933. In: Heilmeyer, WD (ed.), Die Griechische Klassik: Idee oder Wirklichkeit, 61-79. Mainz am Rhein: Philipp von Zabern.

Oechslin, W. 2003. “...bei furchtloser Konsequenz (die nicht jedermanns Sache ist)..." Prolegomena zu einem verbesserten Verständnis des Semper'schen Kosmos. In: Nerdinger, W and Oechslin, W (eds.), Gottfried Semper, 1803-1879. Architektur und Wissenschaft, 52-79. München: Prestel.

Ott, M. 2009. Josef Frank (1885-1967) - Möbel und Raumgestaltung. Unpublished thesis (PhD), Universität Wien. http://othes.univie. ac.at/8539/1/2009-12-16_0002375.pdf.

Ottillinger, E. (ed.). 2009a. Wohnen zwischen den Kriegen. Wiener Möbel 1914-1941. Wien et al: Böhlau.

Ottillinger, E. 2009b. Die 'andere' Moderne, Wiener Wohnungseinrichtungen der Zwischenkriegszeit. In: Ottilinger, E (ed.), Wohnen zwischen den Kriegen. Wiener Möbel 1914-1941, 15-61. Wien et al: Böhlau.

Ott-Wodni, M. 2015. Josef Frank 1885-1967. Raumgestaltung und Möbeldesign. Wien: Böhlau. DOI: https://doi.org/10.7767/9783205793861

Payne, A. 1994. Rudolf Wittkower and Architectural Principles in the Age of Modernism. Journal of the Society of Architectural Historians, 53(3): 322-42. DOI: https:// doi.org/10.2307/990940

Payne, A. 2008. The Pergamon Altar, Heinrich Wölfflin, and German Art History at the Fin de Siècle. RES, 53-54: 168-89. DOI: https://doi.org/10.1086/RESvn $1 \mathrm{~ms} 25608816$
Planer, F. 1912-13. Raumkunst aus der Wiener Frühjahrsausstellung des österreichischen Museums für Kunst und Industrie. Deutsche Kunst und Dekoration, 31: 174-85.

Pozzetto, M. 1983. Max Fabiani. Ein Architekt der Monarchie. Wien: Tusch.

Pozzetto, M. 1984. Karl König e gli architetti del Politecnico. In: Le arti a Vienna. Dalla Secessione alla caduta dell'Impero asburgico, 361-62. Venezia e Milano: Mazzotta.

Pozzetto, M. 1998. Max Fabiani. Trieste: MGS Press.

Prokop, U. 2016. Josef Frank und 'der kleine Kreis um Oskar Strnad und Viktor Lurje'. Zur Problematik der jüdischen Identität von Josef Frank und seinem Kollegenkreis. In: von Thun-Hohenstein, C, Czech, $\mathrm{H}$ and Hackenschmidt, S (eds.), Josef Frank. Against Design. Das anti-formalistische Werk des Architekten, 48-57. Basel: Birkhäuser.

Quitsch, H. 1962. Die ästhetischen Anschauungen Gottfried Sempers. Berlin: Akademie Verlag.

R., H. 1923. Zu Viktor Lurje's Stuckarbeiten. Deutsche Kunst und Dekoration, 51 (February): 280-81.

Rukschcio, B and Schachel, R. 1982. Adolf Loos. Leben und Werk. Salzburg: Residenz Verlag.

Scalvini, ML and Sandri, MG. 1984. L'immagine storiografica dell'architettura contemporanea da Platz a Gedion. Roma: Officina edizioni.

Steinmetz, L. 1921. Viktor Lurje - Wien. Deutsche Kunst und Dekoration, 48 (July): 184-87.

Strzygowski, J. 1907. Die bildende Kunst der Gegenwart. Ein Büchlein für Jedermann. Leipzig: Quelle \& Meyer.

Tauber, C. 2016. La construction de la Renaissance florentine au XIXe siècle. La perspective des voyageurs du Nord. In: Brucculeri, A and Frommel, S (eds.), Renaissance italienne et architecture au XIXe siècle. Interprétations et restitutions, 79-92. Rome: Campisano.

Tournikiotis, P. 1999. The Historiography of Modern Architecture. Cambridge, Mass.: MIT Press. DOI: https://doi.org/10.7551/mitpress/3527.001.0001

Trevisiol, R. 1995. Adolf Loos. Roma Bari: Laterza.

Trevisiol, R. 1996. 'Gli ultimi giorni dell'antichità'. In Denti, G (ed.) Adolf Loos. La cultura del progetto. Roma: Officina.

Van Eck, C. 2004. Modernity and the Uses of History: Understanding Classical Architecture from Bötticher to Warburg. In: Christiansen, $\mathrm{H}$ and Hvattum, $\mathrm{M}$ (eds.), Tracing Modernity, 56-67. London: Routledge.

Von Thun-Hohenstein, C, Czech, H and Hackenschmidt, S. (eds.). 2016. Josef Frank. Against Design. Das anti-formalistische Werk des Architekten. Basel: Birkhäuser.

Welzig, M. 1998. Josef Frank 1885-1967. Das architektonische Werk. Wien: Böhlau.

Witt-Dörring, C. 1996. 'Steel Is Not a Material; Steel Is a Weltanschauung': The Early Furniture Designs of Josef Frank, 1910-1933. In: Stritzler-Levine, N (ed.), Josef Frank Architect and Designer, 102-17. New Haven: Yale University Press.

Wlach, O. 1912. Zu den Arbeiten Josef Franks. Das Interieur, 13(6): 41-45. 
How to cite this article: Cardamone, C. 2020. Varietas, Mediocritas and Annehmlichkeit: The Reception of the Classical Tradition in the Work of Josef Frank and Its Viennese Context. Architectural Histories, 8(1): 5, pp. 1-21. DOI: https://doi. org/10.5334/ah.424

Published: 15 May 2020

Copyright: (c) 2020 The Author(s). This is an open-access article distributed under the terms of the Creative Commons Attribution 4.0 International License (CC-BY 4.0), which permits unrestricted use, distribution, and reproduction in any medium, provided the original author and source are credited. See http://creativecommons.org/licenses/by/4.0\%.

] $\mathrm{u}[\quad$ Architectural Histories is a peer-reviewed open access journal published by Ubiquity Press. 